\title{
THE PROBLEMATIC OF FASHION IN NAZI GERMANY: TWO CASE STUDIES
}

\author{
By \\ Lauriane Duval-Bélair (BA Journalism, Concordia University, 2017)
}

\begin{abstract}
Major Research Project presented to Ryerson University in partial fulfillment of the requirements for the degree of Master of Arts in the program of Fashion
\end{abstract}

Supervisor: Dr. Irene Gammel

Second Reader: Kimberly Wahl

Toronto, Ontario, Canada, 2019

(C) Lauriane Duval-Bélair, 2019 


\section{Author's Declaration For Electronic Submission of a MRP}

I hereby declare that I am the sole author of this MRP. This is a true copy of the MRP, including any required final revisions.

I authorize Ryerson University to lend this MRP to other institutions or individuals for the purpose of scholarly research.

I further authorize Ryerson University to reproduce this MRP by photocopying or by other means, in total or in part, at the request of other institutions or individuals for the purpose of scholarly research.

I understand that my MRP may be made electronically available to the public. 


\begin{abstract}
Whilst very few scholars have paid attention to the role fashion played within Nazi Germany, the topic is highly relevant. As this Master Research Project (MRP) theorizes and documents, the totalitarian regime considered fashion as a tool to extend political control as well as pervasive disciplining of the body and ultimately to manipulate women. At the same time, we also see telling contradictions. Whilst propaganda officially displayed an ideal "Aryan" woman, with her simple peasant dress or traditional dirndl, the practices of the state's leaders' wives diverged from the official female images promoted through propaganda. Indeed, Magda Goebbels (married to the Propaganda minister Joseph Goebbels) and Eva Braun (Adolf Hitler's mistress) remained highly fashionable, sporting the latest Parisian trends in their respective public and private spheres, pointing to the inherent duplicity of Nazi ideology and the practice of its leaders. Using Michel Foucault's theory of power, which posits that power is anchored in the body, along with critical theories of Nazi totalitarianism and fashion theory, this research unpacks a corpus of archival images to bring to light how these women used fashion in ways that helped in the implementation and running of the fascist and murderous state. Throughout the reign of the National Socialist party, fashion and glamour remained a gendered tool in increasing the state's power. Far from innocent, fashion was implicated in the construction of fascist identity.
\end{abstract}




\section{Acknowledgement}

The completion of this Master's Research Paper would have not been possible without the continuous support, encouragement and assistance of many people. First and foremost, I must extend my utmost gratitude to Dr. Irene Gammel who guided me through this process and shared her endless wealth of knowledge and scholarly expertise with me. Thank you Dr. Gammel for the time and energy you have invested in this project, but also for your abounding patience, your optimism and reassurance. I am extremely grateful to have had the chance to work with you. Thank you Dr. Kimberly Wahl for your insight and feedback as a second reader, as well as for your support and guidance all throughout the two years of this degree. I would also like to thank the Ryerson University School of Fashion faculty for opening my eyes to fashion studies. To my fellow classmates, who have become dear friends, thank you for being there and for making this journey so pleasant. I appreciate your friendship more than you can imagine. Finally, I dedicate this project to my family, specifically my mom, Sylvie Duval, and sister, Amélie Bélair, and my closest friends who have provided me with unfathomable support, love and encouragement. Thank you for always believing in me. 
TABLE OF CONTENTS

$\begin{array}{lll}\text { ABSTRACT } & \text { iii }\end{array}$

ACKNOWLEDGEMENT iv

INTRODUCTION

CHAPTER 1: Intersections of Totalitarianism and Women's Fashion: Literature Review and Gaps, Key Theoretical Concepts and Description of Archival Corpus 5

A Framework for Studying Nazi Fashion 8

Corpus of Analysis: The Archival Wardrobe of Two Nazi women 12

CHAPTER 2: Case Study 1: Magda Goebbels' Wardrobe 18

CHAPTER 3: Case Study 2: Eva Braun's Wardrobe 33

$\begin{array}{ll}\text { FIGURES } & 49\end{array}$

CONCLUSION 46

$\begin{array}{lr}\text { BIBLIOGRAPHY } & 69\end{array}$ 


\section{List of Figures}

2.1. Magda Goebbels at the opening of the exhibition "Die Frau" in Berlin, 1933.

2.2. Magda Goebbels with Dr. Raeke at a derby match in Hamburg, 1933.

2.3. National Socialist NS-Frauen Warte, Heft 8, 1935-1936.

2.4. Magda Goebbels on a boat trip on the Wannsee in Berlin, May 1936.

2.5. Magda Goebbels talking to the Greek ambassador, 1936.

2.6. Magda Goebbels at the official reception for the International Association of the Union of Writers and Composers, 1938.

2.7. Jean Harlow in the movie Reckless, 1935.

2.8. Magda Goebbels at the annual Day of National Solidarity for the Winter Relief in Berlin, 1938.

2.9. "Savoir Choisir," Vogue Paris, February 1939.

2.10 a-d. National Socialist NS-Frauen Warte, February 1937. Heft 19, 1938. Heft 23, Maiheft 1939. Heft 21, Maiheft 1942.

2.11. Magda Goebbels walking next to the Prince Paul of Yugoslavia, June 1939.

2.12. "Mousseline et Dentelle," Vogue Paris, June 1939.

2.13. Actress Joan Crawford in the movie Letty Lyon, 1932.

2.14. Magda Goebbels welcomes the prince and princess of Yugoslavia, June 1939.

3.1. Eva Braun and Adolf Hitler at the Berghof, 1937.

3.2: Reel 7 of the private motion pictures of Eva Braun. 1939-1940.

3.3. Eva Braun With Visitors on the Berghof Terrace, 1942.

3.4. “Somptueuses Économies.” Vogue Paris, December 1939.

3.5. Eva Braun and Adolf Hitler looking at photographs, 1942.

3.6. Eva Braun talking to Martin Bormann at the Berghof, 1944. 


\section{INTRODUCTION}

From 1933 to 1945, Adolf Hitler and the National Socialist party controlled Germany using intricate systems of power built upon xenophobic, racist and sexist beliefs that excluded, even persecuted, anyone who did not conform to their state-imposed ideology of anti-Semitism, misogyny, homophobia and ableism. ${ }^{1}$ To support the functioning of its manipulative propaganda and slaughterous politics, the totalitarian state aimed at controlling all aspects of the population's public and private life. From mass murdering a specific section of the nation to dictating the food citizens should eat to banning abortions, they worked to discipline citizens' quotidian lives down to women's garments. ${ }^{2}$ In her book Nazi Chic: Fashioning Women in the Third Reich (2004), historian Irene Guenther suggests that this attempt to dictate dress stemmed from the potent role fashion played as one of the most profitable industries of the country, an industry dominated by Jewish businesses, and as a prominent form of individual and cultural expression of identity. ${ }^{3}$ Aimed at constructing women's appearance in accordance with the regime's National Socialist morals which eschewed makeup and other "frivolous" trends, propagandistic images displayed strong, natural, "Aryan" women sporting traditional folk costumes such as the Bavarian dirndl matched with males in Lederhosen (known as country life fashion or Landhausmode); or farm apparel including sturdy shirts and aprons, while male apparel was heavily dominated by the party uniforms including the Stormtroopers' intimidating "Brown Shirts" (Braunhemden).

\footnotetext{
${ }^{1}$ Matthias Marschik, “A Fascinating Spectacle of Inconsistencies: Eroticism in the Nazi era," European Journal of Cultural Studies 6, no.1 (2003): 96.

2 "One aspect of this manipulation and control over public life was the Nazification of public dress." Kenneth D. McDonald, "Fascist Fashion: Dress, the State, and the Clothing Industry in the Third Reich," (PhD diss., University of California, 1998), 141.

3 "Like art, music, architecture, and film, fashion was chosen as a cultural 'site' where national identity and community were to develop." Irene Guenther, Nazi Chic? Fashioning Women in the Third Reich (Oxford: Berg, 2004), 16.
} 
Beyond promulgating these specific fashion dictates, the regime encouraged women to exclusively select garments crafted in Germany, determined to increase the country's economic profit by proposing a significant competition to the internationally dominant French fashions. ${ }^{4}$ According to Guenther, when the Nazis came to power, German Jews were at the forefront of fashion design in Germany, while Parisian fashion also played a dominating role. Whilst Jews owned half of the German manufacturing firms in 1929, French garments were imported into the country and this rivalry with the German garment industry provoked state-sanctioned criticism and hostility towards French fashion. Guenther further suggests that Parisian-inspired fashion had been denigrated for centuries as frivolous, sexualized and eroticized and, consequently, as harmful, decadent and ill-suited for the childbearing German wives. This defamation of Parisian fashion gained momentum with the emergence of the 1920s "New Woman" and trendy "flapper" - characterized by her shorter hairdo, raised hemline and youthful loose dress - whose physical sartorial liberation was beginning to challenge the traditional gender norms (and the superiority of men). Nazi cultural and fashion critics argued throughout the 1920s and 1930s that the new woman (die Neue Frau) was a French invention not in tune with the Third Reich's ideal of the Nordic (read blond and blue-eyed) and fertile (with a baby or child on her arm) woman advertised in Nazi posters. $^{5}$

Yet despite the state's advocacy for the construction of a physically strong and traditionally dressed "Aryan" femininity, very few women adopted the styles that Nazi propaganda celebrated. Even those influential women ranking very high in the National Socialist elite continued to sport elegant, luxurious garments in line with the supposedly decadent Parisian

\footnotetext{
${ }^{4}$ McDonald, "Fascist Fashion: Dress, the State, and the Clothing Industry in the Third Reich," 102.

${ }^{5}$ Maria Makela, "The Rise and the Fall of the Flapper Dress: Nationalism and Anti-Semitism," Journal of Popular Culture 34, no.3 (2000), 184.
} 
trends. The few scholars who have studied the complex phenomenon of fashion within Nazi Germany, such as Irene Guenther or Kenneth D. McDonald, have argued that the state's mission to discipline fashion did not succeed because the regime and its ideology were fraught with contradictions, suggesting that Nazis ultimately failed to extend their total control to women's dress. But many questions remain, notably interrogations regarding fashion's imbrication in Nazi politics. What does it mean, ultimately, that the wives of Nazi leaders wore the officially verboten French fashion? How did dress and glamour function in the National Socialist totalitarian state? Was Parisian fashion worn by Nazi women truly a resisting force, as Gunther's study suggests, and or was it complicit with Nazi ideology?

To illuminate these uninvestigated relationships, I focus on two high profile women who occupied privileged positions within the oppressive regime and who never stopped wearing elegant and conspicuous attire despite the regime's advocacy of sartorial simplicity and practicality: Magda Goebbels (1901-1945), who married Propaganda Minister Joseph Goebbels in 1931 to become a "first lady" of sorts for the Nazi regime; and Eva Braun (1912-1945), an assistant in the Munich studio of Hitler's official photographer, who rose to become Hitler's long-term mistress and short-lived wife, as the pair married just before committing suicide in 1945, marking the end of the Nazi regime. My study hopes to answer significant and unexplored research questions: What does Magda Goebbels' and Eva Braun's embodied fashion divulge about the intricate power relationships within Nazi Germany? What identities did they construct through fashion and what role did their fashion play in relationship to totalitarian power? To what extent does fashion reveal these women's complicity with the regime?

In order to answer these research questions, this Master's Research Paper (MRP) draws on critical theories of fascism, Michel Foucault's notion of docile bodies as well as fashion 
theory and semiotics to unpack photography and film depicting the women's fashion. By performing an in-depth fashion analysis of two of the most prominent Nazi women's dress choices, as seen through archival photography and video, this MRP challenges earlier arguments that locate moments of resistance in fashion choices. Instead, I suggest that fashion and all of its contradictions remained a gendered tool in increasing the state's power. As I shall argue below, elite members of the regime deliberately used clothing as a way to manipulate citizens' perceptions of the regime and extend totalitarian domination whilst ensuring wide-spread support all throughout the reign of the Reich. In short, this study takes a multi-directional focus querying and studying how these advantaged Nazi women used fashion (1) as a public symbol of illusory normality and freedom; (2) as a device to help increase the prestige of the party both at the home front and internationally; (3) as an escapist coping mechanism; and (4) as an instrument towards aspirational identity construction within the Nazi hierarchy.

This MRP involves a corpus drawn from archival photographs, propaganda images, letters, diaries, magazines and other relevant documents available online via a variety of archives. This corpus will be introduced in chapter 1, which also reviews the existing scholarly literature on the topic of Nazi women and fashion, developing a theoretical framework used to explore fashion under a fascist regime of power. This essay then moves to the two case studies, Magda Goebbels (chapter 2) and Eva Braun (chapter 3), in separate and yet thematically interlinked chapters. Collectively, the following chapters reveal the profoundly gendered and manipulative strategies in the construction of women's Nazi sartorial identity within the Third Reich. 


\section{CHAPTER 1: Intersections of Totalitarianism and Women's Fashion: Literature Review and Gaps, Key Theoretical Concepts and Archival Corpus}

Since the 1980s, scholarship about Nazi women has evolved from a debate surrounding this inquiry: were women predominantly victims or were they fellow perpetrators of the Reich's atrocities? $?^{6}$ In "Equality and Difference in National Socialist Racism," German historian Gisela Bock exonerates German women by arguing that the Nazi state was patriarchal and sexist, persecuting women in similar ways to how it persecuted "non-Aryan" population, therefore, leaving little responsibilities to its female citizens. ${ }^{7}$ In contrast, the American scholar Claudia Koonz reminds us that Nazi women were involved in the Holocaust since they "made possible a murderous state in the name of concerns they defined as motherly." Art historian Katherine Rossy in her essay "Politicizing Pronatalism: Exploring the Nazi Ideology of Women Through the Lens of Visual Propaganda" further explores the motherhood rhetoric through a focus on propaganda images and magazines. The scholar argues that propaganda was utilized as a way to separate female and male spheres, positioning motherhood as the most imperative feature of a woman's life. ${ }^{9}$

Yet many female success stories reveal that some women departed from the traditional procreation path. Sports scholar Annette R. Hofmann's documents the case of Christl Cranz, one

\footnotetext{
${ }^{6}$ For an overview, see Ralph M. Leck, "Theoretical Issues: Conservative Empowerment and the Gender of Nazism: Paradigms of Power and Complicity in German Women's History," Journal of Women's History 12, no. 2 (2000): 149.

${ }^{7}$ Gisela Bock, "Equality and Difference in National Socialist Racism," in Beyond Equality and Difference: Citizenship, Feminist Policies and Female Subjectivity, ed. Gisela Bock and Susan James (London: Routledge, 1992), 97.

${ }^{8}$ Claudia Koonz, Mothers in the Fatherland: Women, the Family and Nazi Politics (New York: St. Martin's Press, 1987), 5.

${ }^{9}$ Katherine M. Rossy, "Politicizing Pronatalism: Exploring the Nazi Ideology of Women Through the Lens of Visual Propaganda," The Graduate History Review 3, no.1 (2011): 50.

See also Barbara McCloskey, "Marking Time: Women and Nazi Propaganda Art during World War II," Contemporaneity 2, no.1 (2012): 3-4. "For this study, I surveyed approximately [sic] six hundred German posters of the Second World War. [...] Only thirty-three contained images of women."
} 
of the most successful German skiers between 1934 and 1939 who achieved great public appreciation during the National Socialist era. Considering the selected blessing the Nazi government granted Cranz and other female sports figures and women, certain emancipated women were strategically encouraged by the regime and became figureheads for the party. ${ }^{10}$ This is also evidenced in the case of the blond female saxophonist Ingrid Larssen who enjoyed great success during the Third Reich even though the instrument itself was partially banned by the Nazi regime being associated with the supposed decadence of modern jazz.

In the wake of this plethora of studies on women in Nazi Germany, scholars have only just begun to discuss the linkage of Nazism and fashion. Roberta S. Kremer's volume of essays Broken Threads: The Destruction of the Jewish Fashion Industry in Germany and Austria (2007) discusses the Jewish fashion industry and how it was systematically and relentlessly destroyed during the Third Reich. ${ }^{11}$ Torsten Homberger and Linda Arthur Bradley have focused on the use of uniforms as "one of the most important similarities of fascists across Europe," with Nazis using their uniforms specifically to influence public opinion (notably through intimidation) and to project the party's ideology onto the body. ${ }^{12}$ Comparing Stalinist and Bolshevik fashioning of women and politics with those of Nazi Germany, Victoria Vygodskaia Rust has argued that both Russian and German dictatorships capitalized on fashion to paradoxically "constrict women's rights" whilst granting them some freedom, an argument aligning with Foucauldian theories of power and resistance. ${ }^{13}$

\footnotetext{
${ }^{10}$ Annette R. Hofmann, “Christl Cranz, Germany's Ski Icon of the 1930s: The Nazis' Image of the Ideal German Woman?" Sport in Society 20, no.8 (2017): 1026.

${ }^{11}$ Roberta S. Kremer, ed., Broken Threads: The Destruction of the Jewish Fashion Industry in Germany and Austria (Oxford: Berg, 2007), 3.

12 Torsten Homberger and Linda Arthur Bradley, "Nazi Dress: Hitler's Storm Troopers and Appearance Management, 1921-1933," Critical Studies in Men's Fashion 2, no.2-3 (2015): 183.

${ }^{13}$ Victoria Vygodskaia Rust, "Fashioning Women Under Totalitarian Regimes: 'New Women’ of Nazi Germany and Soviet Russia," (PhD diss., Washington University, 2012), 5.
} 
Matthias Marschik has also established the importance of fashion as a seductive method used by the state to reinforce and maintain power. ${ }^{14}$ For example, whilst the Nazi regime publicly disapproved of Parisian-inspired fashionable attire, it also encouraged women to attend the League of German Girls (Bund Deutscher Mädel or BdM) meetings with the promise of a fashion show at the end. ${ }^{15}$ Marschik further documents that the regime allowed women to wear fashionable clothing as a technique to find male partners and augment the birth rate. The American historian S. Jonathan Wiesen specifically explores how these incoherencies were rooted in economic interests, as the consumption (and the production) of German goods was imperative to maintain a good state economy; and a healthy economy was crucial to the fulfillment of the state's military goals. ${ }^{16}$

The only full-length book study in English, Irene Guenther's Nazi Chic?: Fashioning Women in the Third Reich (2004), investigates a spectrum of fashion, ranging from high officials to the working class and to the Jewish women in concentration camps. Whilst providing significant context for the current MRP, Guenther's argument that the Nazi government ultimately failed in fashioning women or in disciplining their sartorial desires and tastes, I suggest is an overly positive reading, one that needs to be questioned especially with respect to the privileged Nazi women, who both internalized the Nazi ideology and represented the regime publicly and privately in their fashion. ${ }^{17}$ Consequently, the considerable scholarly gap that

\footnotetext{
${ }^{14}$ Nathan Stoltzfus, Hitler's Compromises: Coercion and Consensus in Nazi Germany (New Haven: Yale University Press, 2016), 13.

${ }^{15}$ Marschik, “A Fascinating Spectacle of Inconsistencies," 104.

16 "While one might suspect that ads bore the hallmarks of Nazi Racial ideology - blond subjects, anti-Semitic language, and conservative gender roles - the reality is that ad motifs varied widely and often did not reflect anything uniquely 'German' or 'National Socialist.' The contradictions abounded. Fashion magazines highlighted the new woman in ways that were indistinguishable from American advertising (sometimes she even had a cigarette in her hand)." Wiesen, Creating The Nazi Marketplace, 67.

17 Guenther, Nazi Chic?, 265.
} 
remains to be explored concerns the role of fashion in encoding these fashionable women's complicity in the regime.

The two subjects I have chosen are also underexplored in the scholarship. Despite the plethora of studies devoted to Magda Goebbels and Eva Braun, few authors have delved into their fashion habits. Biographers such as Hans Otto Meissner's Magda Goebbels: The First Lady of the Third Reich (1980) and Heike B. Görtemaker's Eva Braun: Life With Hitler (2011) confine their fashion research to a few token sentences about the women's toilette and makeup routine, while Anna Maria Sigmund's Women of the Third Reich (2000) and Guido Knopp Hitler's Women (2003) focus on the women's evolving relationships with the powerful men of the regime. In short, the exploration of National Socialist propaganda, women and fashion and the pernicious dynamics of Nazi power remains to be investigated with a focus on Magda Goebbels, who represents a highly visible Nazi woman and Eva Braun, who represents the Nazi leader's private and secret life, making these two studies complementary. Before introducing my corpus more extensively, I will now introduce my theoretical framework of analysis.

\section{A Framework for Studying Nazi Fashion}

Establishing a theoretical framework to grasp the complex operations of Nazi fashion necessitates first an understanding of totalitarianism, a difficult concept given the considerable variations between the world's inconstant fascist regimes. Hitler's totalitarianism was different from Joseph Stalin's in Russia, which was different from Benito Mussolini's in Italy and Francisco Franco's in Spain. According to Hannah Arendt's influential 1951 book Origins of Totalitarianism, totalitarianism involves charismatic leaders who display quasi-mythical 
qualities. $^{18}$ They hold complete control of a nation's public and private life using terror, violence and propaganda as a strategy to fulfill their ideological goals and to maintain their concentrated authority. As social and political scholar Karl W. Deutsch writes, the strength of the totalitarian regime lies in its paradoxical ability to apply power selectively and in Nazi Germany targeting most virulently the German Jewish minority while refraining from using violence against the entire nation. ${ }^{19}$ Whilst some argue that the Great Depression (which started in 1929 and continued into the 1930s) permitted the Nazi regime to be democratically elected by targeting lower classes and promising them prosperous days, Else Frenkel-Brunswick argues that beyond economy, psychology helps to explain the appeal of a fascist regime to the public. ${ }^{20}$ As she writes: "Totalitarianism seems to create the illusion and emotional appeal, that merely embracing its ideology confers a kind of magical participation in the source of all power and this provides absolute salvation and protection." 21 Therefore, alongside the use of violence and terror, calculated strategies of psychological manipulation and staged performances helped engender the Nazis' intended mesmerizing appeal at a time of great mass fear and anxiety, ultimately bestowing the Nazi regime with crucial nation-wide obedience all throughout its twelve-year reign.

Moreover, in Hitler, Stalin and Mussolini: Totalitarianism in the Twentieth Century (2015), Bruce F. Paul reminds us that totalitarian regimes often modify their ideologies for

\footnotetext{
${ }^{18}$ For similar arguments regarding the leader as a charismatic personality, see also Alex Inkeles, "The Totalitarian Mystique: Some Impressions of the Dynamics of Totalitarian Society," in Totalitarianism, ed. Carl J. Friedrick (New York: The Universal Library, 1954), 88-91; and Robert O. Paxton argues in the 2004 book The Anatomy of Fascism that Hitler calculated his public appearances to charm and manipulate the public into supporting the movement and the leader. Robert O. Paxton, The Anatomy of Fascism (New York: Vintage Books, 2004), 65-66.

${ }^{19}$ Karl W. Deutsch, "Cracks in the Monolith : Possibilities and Patterns of Disintegration in Totalitarian Systems," in Totalitarianism, ed. Carl J. Friedrick (New York: The Universal Library, 1954), 314.

${ }^{20}$ Else Frenkel-Brunswick, "The Role of Psychology in the Study of Totalitarianism," in Totalitarianism, ed. Carl J. Friedrick (New York: The Universal Library, 1954), 172.

${ }^{21}$ Frenkel-Brunswick, "The Role of Psychology in the Study of Totalitarianism," 173.
} 
"tactical purposes." 22 Since the regime feared mass dissent, scholar Nathan Stoltzfus argues in Hitler's Compromises: Coercion and Consensus in Nazi Germany (2016), that it made considerable compromises and changes to its ideology to ensure public compliance. Stoltzfus further suggests that Hitler himself strategically made concessions as a way to "safeguard his prestige" and maintain his role as a hero who had the well-being of his citizens at heart. ${ }^{23}$

This dichotomy between omnipresent power and strategic compromises can be understood in light of Foucault's theory of the docile body and of resistance. According to Foucault, modern society is maintained by the use of invisible discipline and control over individuals' bodies, a mechanism explained through the architectural metaphor of the Panopticon. ${ }^{24}$ Jeremy Bentham's eighteenth-century Panopticon was a round prison with a tower at the center offering the guards a view into every single cell of the building. Walls would separate each cell, preventing inmates from seeing each other or from seeing the guard, an ingenious architectural design that helped to avoid rebellions and collective escapes. ${ }^{25}$ Since inmates were not able to see into the tower, they had no means of knowing if they were being watched or not. This panoptic schema metaphorically illustrates how modern power immerses the individual into "permanent visibility that assures the automatic functioning of power." ${ }^{26}$ In other words, individuals invariably act as if they were being watched, whereby surveillance becomes permanent. This type of society of surveillance creates what Foucault calls "docile bodies," which follow internalized norms and rules. According to Karl W. Deutsch, this

\footnotetext{
22 Bruce F. Pauley, Hitler, Stalin and Mussolini: Totalitarianism in the Twentieth Century, 4th ed. (Chichester: John Wiley \& Sons, Inc, 2015), 11.

${ }^{23}$ Stoltzfus, Hitler's Compromises: Coercion and Consensus in Nazi Germany, 2.

${ }^{24}$ Michel Foucault, “'Panopticism' from Discipline \& Punish: The Birth of the Prison,” Race/Ethnicity: Multidisciplinary Global Contexts 2, no.1 (Autumn 2008): 1-12.

${ }^{25}$ Foucault, “'Panopticism' from Discipline \& Punish," 5.

${ }^{26}$ Foucault, “"Panopticism' from Discipline \& Punish,” 6.
} 
Panopticon schema was visible in Nazi Germany since the majority of the population obeyed to the National Socialists rules without any monitoring because the probability of surveillance was high enough to enforce the habits of obedience, transforming the free German population into the docile bodies Foucault was referring to. As Foucault writes: "Of course, no state could have more disciplinary power than the Nazi regime."27

At the same time, by granting small compromises, the regime accommodated resistance, which according to Foucault, is part of the function of power itself, as no domination can exist without some kind of opposition. ${ }^{28}$ Whilst the two case studies that will be examined below were obviously not opposing the regime (Magda Goebbels was a proud member of the party and Eva Braun shared her life with the dictator himself), examining their fashion habits permits an understanding of how fashion transgressions were publicly staged by the elite and tolerated for most women during the Third Reich. Fashion was constituent of this complex operation between total domination and compromises, reminding us of the insights of fashion and phenomenology scholars, such as French philosopher Maurice Merleau-Ponty, who argues that the body is not an inert object separated from the mind but is the active envelope of one's identity through which humans experience and understand the world. ${ }^{29}$

Garments cannot be considered merely for their practicality but demand to be understood, as sociology scholar Diana Crane writes, as strong tools for constructing identity. ${ }^{30}$ In the

\footnotetext{
${ }^{27}$ Michel Foucault, "Society Must Be Defended" Lectures At the Collège de France, 1975-76, ed. Mauro Bertani, Alessandro Fontana and François Ewald, trans. David Macey (New York: Picador, 1997), 259.

28 "Domination is in fact a general structure of power whose ramifications and consequences can sometimes be found descending to the most recalcitrant fibers of society. But at the same time it is a strategic situation more or less taken for granted and consolidated by means of a long-term confrontation between adversaries." Michel Foucault, "The Subject and Power," Critical Inquiry 8, no. 4 (Summer 1982): 795.

29 "Other human beings are never pure spirit for me: I only know them through their glances, their gestures, their speech - in other words, through their bodies." Maurice Merleau-Ponty, The World of Perception, trans. Oliver Davis (London: Taylor \& Francis Group, 2008), 93.

${ }^{30}$ Diana Crane, Fashion and its Social Agendas: Class, Gender and Identity in Clothing (Chicago: The University of Chicago Press, 2000), 1.
} 
process, clothing works as a form of vocabulary, just like a spoken language, providing information about the wearer as well as affecting and influencing others' perceptions. ${ }^{31}$ According to Susan Kaiser, "appearance management becomes a means for self-presentation - a process of displaying an identity to others in a social context." ${ }^{32}$ These fashion theories posit clothing as a potent mechanism, which can be manipulated, perhaps best seen in the widespread adoption of uniforms used by the Nazis, as Kenneth D. McDonald writes, to reinforce "their authoritarian system of power.. ${ }^{, 33}$ As a result, by merging totalitarian theories with Foucault's notions of the docile bodies and resistance with a strong, insightful understanding of fashion, this research aims at exploring the meaning of the sartorial representation, through a corpus that now requires a brief introduction.

\section{Corpus of Analysis: The Archival Wardrobe of Two Nazi women}

As the wife of the Reich Propaganda Minister, Joseph Goebbels, Magda Goebbels was one of Hitler's most fervent supporters. Throughout the twelve years of the Third Reich, Frau Goebbels assumed the role of the official mother of the nation, embodying the regime's ideology of the perfect "Aryan" child-bearer: she gave birth to six children during her marriage with Goebbels (she also had a son with her previous husband), appeared in leading magazines and newspapers of the period, gave radio interviews and attended public events alongside Hitler. She attended events internationally such as the Venice Film Festival in 1939 and represented the country at home at the Berlin Olympics in 1936. Her role was so vital to the public image of the Reich that Hitler believed she could embody the female version of himself, using her charm, prestige and

\footnotetext{
${ }^{31}$ Alison Lurie, The Language of Clothes (New York: Random House, 1981), 5.

${ }^{32}$ Susan Kaiser, The Social Psychology of Clothing: Symbolic Appearances in Context, 2nd ed. (New York: McMillan, 1990), 181.

${ }^{33}$ McDonald, "Fascist Fashion: Dress, the State, and the Clothing Industry in the Third Reich," 198.
} 
elegance to entice people to adhere with the movement's ideology. ${ }^{34}$ Hitler deemed Frau

Goebbels as someone who could boost the status, the power and the influence of the party and of its dictator. ${ }^{35}$ Magda Goebbels' biographer Otto Hans Meissner categorizes her as a “decisive gain for the Nazis" whose wealth and international prestige greatly participated in the success of the party. ${ }^{36}$

Because she was tasked with crucial public duties, there is a substantial body of archival photography documenting Magda Goebbels' public appearances through magazines and newspapers. Most of Magda Goebbels' photographs that will be explored in the following chapter were accessible to the German citizens during the Third Reich and are now publicly available on various archival platforms, such as the German photo agency Ullstein Bild, the Prussian Cultural Heritage Foundation image archives' BPK-Bildagentur, Getty Images and more. Many of these images come from the archives of Heinrich Hoffman (1885-1957), the party's official photographer, which were seized by Americans in 1945 and brought to Washington in 1951, containing thousands of images. In order to explore how Goebbels' fashion choices connected with the trends of the period, these images will be analyzed at times in comparison with the Parisian Vogue archives - which are accessible online through the French Bibliothèque Nationale de France's digital platform Gallica - as well as with the female National Socialist magazine NS-Frauen-Warte (1934-1945) archives. The archives of the NS-FrauenWarte are available online through the Heidelberg University Library digital archive collections.

\footnotetext{
34 “'This woman could play an important part in my life, even if I was not married to her. She could play the opposite, female pole to my one-sidedly masculine instincts....A shame that she is not married,' said Hitler.” Anja Klabunde, Magda Goebbels, trans. Shaun Whiteside (London: Little, Brown, 2001), 142.

35 "Hitler would have meant a huge boost in her status, and at the same time given her an unexpected proximity to power and influence." Klabunde, Magda Goebbels, 143.

36 "She 'was to make the Nazis socially acceptable'." Hans Otto Meissner, Magda Goebbels: The First Lady of the Third Reich, trans. Gwendolen Mary Keeble (New York: The Dial Press, 1980), 91.
} 
If Magda Goebbels publicly represented Nazi Germany, Eva Braun experienced life in the Third Reich very differently. Braun first met Adolf Hitler at Heinrich Hoffman's studio where she was working as a photographer's assistant and their affair is believed to have started between 1931 and 1932 when the young woman would have been only nineteen or twenty years old, with Hitler more than twenty years her senior. From the early years of their relationship up until their communal suicide in 1945, many biographers have asserted that Braun was kept completely hidden from the public, living the last years of her life predominantly secluded at Hitler's private villa, the Berghof in Obersalzberg in Bavaria close to the Austrian border. In spite of that concealed life, important collections of Braun's private photographs, videos, diaries and assets survived the war. Specifically, my corpus includes a collection of eight private videos, called "Eva Braun Private Motion Pictures," shot at various locations such as at the Berghof, in Munich and on holiday, between circa 1938 to 1944. These private silent motion pictures, which are now held at The United States Holocaust Memorial Museum, were shot on $16 \mathrm{~mm}$ films originally in black and white and in colours, totalizing over four hours of footage. These videos, which have been digitized and are now available to the public through the United States Holocaust Memorial Museum's online archival platform, feature various key members of the Nazi elite, including Adolf Hitler as well as Eva Braun herself and offer an insightful glimpse into Braun's life. According to Eva Braun's biographer, Angela Lambert, these videos were in great parts shot by Braun herself, using an extremely professional film camera (likely a gift from Hitler from 1937 or 1938). ${ }^{37}$ Eva Braun was known to enjoy taking photos and videos as evidenced also in photographs depicting her holding a camera or shooting videos. ${ }^{38}$ She had

\footnotetext{
${ }^{37}$ Angela Lambert, The Lost Life of Eva Braun (New York: St Martin's Press, 1984), 173.

${ }^{38}$ Heike B. Görtemaker, Eva Braun: Life With Hitler, trans. Damion Searls (New York: Alfred A. Knopf, 2011), 190.
} 
learned the craft by working at Hoffmann's photo studio in Munich where she was trained on how to process her own photos; once she became Hitler's mistress and was relieved of her professional duties as a photographer's assistant, she spent her free time experimenting with photography and video using up-to-date equipment. ${ }^{39}$ For example, the colour technology she used in these motion pictures was still relatively new in the 1930s and was usually reserved for professional use.

Besides the surviving videos, Braun's thirty-three private photo albums (with photography taken by her and probably by her sister Gretl) also represent an important part of this corpus and further reinforce Braun's use of high-quality professional photographic equipment and paper that produced photos that "haven't faded or deteriorated as cheaper stock would have done. ${ }^{, 40}$ Clearly not an amateur, she used professional twin-lens Rolleiflex - another gift from Hitler - "a camera that within a few years would be in demand all over the world for its advanced features and outstanding results." ${ }^{41}$ That said, only the 33 albums that Braun and her sister Gretl put together (with a selection of images) survived. This corpus also includes images shot by Heinrich Hoffman during his visits at the Berghof. All of these photographs are available through online archival platforms, such as the Bayerische Staatsbibliothek's online Bildarchiv, the BPK-Bildagentur or Getty Images.

Besides this visual material, Eva Braun also left behind sixteen sheets of her diary written from February 1935 to May 1935, which was later translated into English and is now available online through the United States National Archives. This diary is part of the American Foreign Records Seized Collection, Group 242 and was seized circa 1946. Even though this diary covers

\footnotetext{
${ }^{39}$ Lambert, The Lost Life of Eva Braun, 168.

${ }^{40}$ Lambert, The Lost Life of Eva Braun, 168.

${ }^{41}$ Lambert, The Lost Life of Eva Braun, 168.
} 
only a narrow segment of Eva Braun's life alongside Hitler's, it does provide some key insights into the nature of their early relationship. Supplementing this diary, the National Archives offices at College Park in Maryland also generously shared with me a digital version of Eva Braun's Assets from 1945, which is part of the Records of U.S. Occupation Headquarters, World War II, 1923-1972 Collection. This inventory of Eva Braun assets includes a detailed description of her silverware, jewelry, watches and money that was found at the end of the war and will also be referenced in chapter 3 .

As suggested by this corpus, this study draws on photographs, propaganda images and other ephemera because the dresses that were worn by Goebbels and Braun are no longer available for scholars to study as material objects. Consequently, the goals and methods are to unpack the political and ideological dimensions of the wardrobe of two Nazi women using fashion images, that is, representations of their garments and styles, some of which circulated privately while others circulated in the mass media. To bring to light the meanings concealed in these fashion representations, this study applies the theory of French semiologist Roland Barthes, which draws from Ferdinand de Saussure linguistic semantics asserting that humans have a natural capacity for constructing a language that works as a "system of distinct signs corresponding to distinct ideas." ${ }^{42}$ Barthes applied Saussure's science of the sign to fashion in his 1967 book The Fashion System, which posits fashion as a sign that can be read or decoded, operating similarly to the rules of language. According to Barthes, clothing can be analyzed under three different structures: the real garment (or the material artifact), the image-clothing (or the photographed clothing) and the written-garment (or the textual description of a garment).

\footnotetext{
${ }^{42}$ Ferdinand de Saussure, Course in General Linguistics, ed. Perry Meisel and Haun Saussy, trans. Wade Baskin (New York: Columbia University Press, 2011), 10.
} 
Barthes prioritizes the latter two, focusing on the dynamics of representation. ${ }^{43}$ The sign operates through a duality of signifier (word or figure) and signified (the meaning assigned by a specific cultural context). Meaning arises from breaking down signifiers into various units and observing combinations and equivalences through a layering of denotative and connotative analysis; ${ }^{44}$ denotation simply refers to the objective characteristic of a dress while connotation draws from an object's symbolism and emotional significance embedded into the social, political and historical context of the garment. Semiology is interested in what the garment or the combination of garments signify meanings beyond what is literally denoted. Moreover, a sign can also become a myth when the sign itself (created from the connection between a signifier and a signified) becomes a signifier for a secondary set of signification. As Malcolm Barnard reminds us in the book Fashion as Communication, signs are often arbitrary as there is nothing that associates blue with boys and pink with girls, other than social agreement and cultural, political and social contexts. Yet these fashion codes are rooted in the connotation of signs and provide meaning.

As we shall see, each garment functions as a sign conveying a meaning that unfolds under a Foucauldian analysis, revealing that the fashion styles of Goebbels and Braun were not isolated cases, but anchored in the era's time and space. Through my intersection of Foucauldian theory with fashion and semiotics, I now turn to analyzing the functioning of fashion as a tool of power. Chapter 2 is dedicated to exploring Magda Goebbels as a case study: putting the focus on how one of the most influential women of the Reich used fashion to extend the power of the regime.

\footnotetext{
${ }^{43}$ Roland Barthes, The Fashion System, trans. Matthew Ward and Richard Howard (New York: Hill and Wang, 1983), 8. See also Roland Barthes, Mythologies, trans. Annette Lavers (London: Jonathan Cape, 1972), 110. 44 "Meaning depends neither on the object nor on its qualification, but rather, at the very least, on their combination." Barthes, The Fashion System, 60.
} 


\section{CHAPTER 2: First Case Study: Magda Goebbels' Wardrobe}

Before examining Magda Goebbels' fashion, let us recall the prominent position Frau Goebbels held in Hitler's regime, where she was given a significant public platform becoming an influencer with a reach over millions of women. Blonde, blue-eyed, surrounded by children, she was the first woman to receive the Honour Cross of the Mother, a prestigious Nazi recognition that was awarded to women of four children or more. ${ }^{45}$ On Mother's Day, in May 1933, Magda granted a radio interview, reinforcing her role as the mother of the nation. She also performed many public duties for Hitler, often representing the regime at state functions. Frau Goebbels was so influential that Hitler did not grant her request to divorce her husband, the philandering Joseph Goebbels, in 1938 lest it destroys the "idyllic family image" they bore. ${ }^{46}$ In playing a potent political role in the dissemination of Nazi ideology, how did Frau Goebbels stage her public appearances using fashion? How do these performances give insight into the inner functioning of the Third Reich?

It is widely accepted within the field of fashion theory that sartorial display works as a complex social act and that clothing is invested in political meanings and experiences. ${ }^{47}$

Nowhere is this more evident than during the first official appearance of Magda Goebbels, which occurred just two months after Hitler's January 1933 appointment as chancellor. In March 1933, on the occasion of the opening of the exhibition Die Frau, photographer Robert Sennecke captured Frau Goebbels as she was performing a speech at the reception (figure 2.1), an image that was also published in the Italian newspaper Tempo in April 1933. Since this photograph represents Goebbels' first official appearance on behalf of the newly elected National Socialist

\footnotetext{
45 Anna Maria Sigmund, Women of the Third Reich (Richmond Hill: NDE Publishing, 2000), 84-85.

${ }^{46}$ Klabunde, Magda Goebbels, 269.

47 Wendy Parkins ed., Fashioning the Body Politic: Dress, Gender, Citizenship (Oxford: Berg Publishers, 2002), 12.
} 
party, Frau Goebbels' self-fashioning on that event is all the more relevant as this exhibition was the fruit of the propaganda bureau's work led by her husband and the occasion was to set the stage for future appearances.

For the exhibition opening, Frau Goebbels wore a black short-sleeved wrapped bust dress adorned with two-tone semicircle appliqués on the breast and on the sleeves. Her two-tone hat is matching the dress and she accessorized the attire with a single string of pearls around her neck as well as pearl earrings. The nipped waistline, lower neckline and the appliqués drawing attention to the upper body all align with the widespread 1930 s sartorial trends. ${ }^{48}$ Not only was this silhouette fashionable at the period, but the combination of the black and white was highlighted as a key style of the season in the July 1933 edition of Vogue Paris. ${ }^{49}$ In fact, the June 1933 issue of Vogue Paris states that black was the colour of Parisian elegance and refinement. These parallels with Parisian garments present the signifier (or Magda's attire) which connotes trendiness and sophistication, positioning Frau Goebbels' look as a symbol of the period's international fashion codes.

In spite of embodying Parisian refinement, Magda decided to keep her necklace and earrings dainty and small, abstaining from making an ostentatious statement of regal grandeur, preferring a subtle hint at her high social rank. Moreover, her colours are muted with few ornamentations, not unlike the fashions of the women in the audience. For example, the woman on Magda's left is also wearing a two-tone hat with a similar contrasting appliqué on her dress and a pearl necklace. This analogy between Magda's look and her audience's style is highly important because as Barthes asserts, meanings arise from observing equivalences and

\footnotetext{
${ }^{48}$ Charlotte Fiell and Emmanuelle Dirix, eds., 1930s Fashion: The Definitive Sourcebook (London: Goodman Fiell, 2012), 14.

49 "Vu à Paris," Vogue Paris, July 1933, 29.
} 
oppositions as significations change according to the context and the spatial positioning of a signifier in regards to its environment. ${ }^{50}$ This composition's multiplication of muted attires in close proximity engenders an effect of understatement, blending Magda in with the rest of the crowd. Ultimately, this photograph points to how Frau Goebbels was fashioning herself to appear as both a leader and a "normal" German woman.

This understatement gains substantial significance when compared to Frau Goebbels' other looks of the period. As the semiotician Daniel Chandler writes, "signs are not meaningful in isolation, but only when they are interpreted in relation to each other." ${ }^{, 51}$ For example, only a few months after this first appearance, Magda Goebbels was photographed at a derby match in Hamburg (figure 2.2) wearing a floral calf-length dress heavily ornamented with a ruffled bib, a jacket with fur cuffs, patent high heels and a hat decorated with a floral pattern. When measuring this look against the fashion of Die Frau exhibition opening, it becomes apparent that Frau Goebbels chose to fashion herself in line with what the other German women were wearing, by cutting down on ornamentation and conspicuous luxury.

This representation of fashion signifies how Goebbels used garments to give the illusion of stability and to reassure German women, most of whom look serious and somewhat skeptical in the photo, just months after Hitler's election. We are reminded of Matthias Marschik's observation that public apparel was used to maintain the appearance "of normal conditions," as a way to avoid possible revolts and to ensure perpetual loyalty. ${ }^{52}$ Deliberately feigning that nothing was changing within Germany was a strategic approach that is also discernible in an interview Frau Goebbels granted the newspaper Alpenzeitung in July 1933 during which she asserted that

\footnotetext{
50 "We must then compare these segments with one another [...] so as to determine according to which oppositions they produce different meanings." Barthes, The Fashion System, 59.

${ }^{51}$ Daniel Chandler, Semiotics: The Basics (London: Routledge, 2002), 147.

${ }^{52}$ Marschik, “A Fascinating Spectacle of Inconsistencies," 101.
} 
the Nazis' ideology did not request that women stop wearing makeup or smoking. ${ }^{53}$ She even stated that women should be as beautiful and as elegant as possible and that fashion did not have anything to do with immorality, a point also made visually in a 1935-1936 issue of the Nazi publication NS-Frauen-Warte (figure 2.3), showing women in form-fitting evening dresses made of sensuous silk and velvet. This tactical contradiction reminds us of Hans Peter Bleuel findings, in his 1973 book Strength Through Joy: Sex and Society in Nazi Germany, that the propaganda minister himself capitalized on strategic contradiction for psychological manipulation. Indeed, in 1934 Joseph Goebbels publicly criticized the supposed "nonsense" of the strict moral arbiters asking women to not smoke or dress up as a way to publicly reassure the citizens that they had nothing to fear from the Nazi regime. ${ }^{54}$ Frau Goebbels' fashion attire worked in a congruous manner.

In August 1936, the party's official photographer Heinrich Hoffmann photographed Frau Goebbels with her daughter Hilde and the Prince Umberto II of Savoyen during a boat trip on the Wannsee in Berlin (figure 2.4), an image published by the Berliner Morgenpost. For that nautical outing, Frau Goebbels donned a floral dress with a V-neck, cinched waist and voluminous shoulders ornamented with ruffles. As usual, Frau Goebbels is also wearing a necklace. The layered ruffles on the shoulders as well as the deep V-cut neckline connote the garment with codes of "femininity" and delicacy. The floral pattern also stands for womanhood because the soft and delicate nature of flowers is known to imbue the women's body with gendered normative ideals of beauty and health. ${ }^{55}$ Through these traditionally "feminine" garments, Frau Goebbels intensified a specific aspect of her public charisma by displaying her identity as an

\footnotetext{
53 "Die Deutsche Frau in Neuen Reich: Gespräch mit Magda Goebbels," Alpenzeitung, July 9, 1933.

${ }^{54}$ Hans Peter Bleuel, Strength Through Joy: Sex and Society in Nazi Germany, trans. J. Maxwell Brownjohn (London: Secker \& Warburg, 1973), 75.

${ }^{55}$ Lurie, The Language of Clothes, 210.
} 
attractive, non-threatening and sweet woman, even as she posed in front of the oversized stark Nazi symbol raised on the flag immediately behind her. Completely opposing her dress's symbol, the flag is the emblem the Nazi regime and is connoted with violence, racism and brutality. The antagonistic natures of these two signs are fortified by the straight and geometrical lines of the flag contrasting with the abstract floral pattern of the dress. By closely juxtaposing two conflicting signifiers, Magda Goebbels is rhetorically manipulating the meaning of this photograph as a strategy to separate and emphasize the contrast between her charismatic self and the violent deeds of the regime. In this composition, her innocence and femininity as connoted in her garments rhetorically spilled over the flag, neutralizing and softening the Nazi symbol of the Swastika. This manipulation of the sign is further reinforced by the fact that Magda is accompanied by her daughter, emphasizing her role as a caring mother. This strategy reminds of us of Barthes' theory of Neither-Norism, which "consists in stating two opposites and balancing the one by the other so as to reject them both." ${ }^{, 56}$ Evidently, Goebbels's fashion works rhetorically to equilibrate and alleviate the violent symbol of the Nazi regime.

This eagerness to draw attention away from the violence of the state and to her motherly charisma points to the fact that Nazi popularity rested on their public image and on the adulation of its leaders. As a result, "Nazis often presented themselves in a charming, cooperative, "nonpolitical' vein. ${ }^{, 57}$ Magda enjoyed public admiration and veneration, receiving mail from the public because "she came so close to the ideal of motherhood propagated by the party." ${ }^{\text {, }}$ Most of the letters asked for help regarding various household, marital and domestic difficulties and each letter received an answer with the assistance of Magda's private secretary hired specially to

\footnotetext{
${ }^{56}$ Barthes, Mythologies, 153.

${ }^{57}$ Albert Lauterbach, "Totalitarian Appeal and Economic Reform," in Totalitarianism, ed. Carl J. Friedrick (New York: The Universal Library, 1954), 239.

${ }^{58}$ Klabunde, Magda Goebbels, 225.
} 
help with the mail. ${ }^{59}$ Frau Goebbels' ability to connect with her audience remained an important part of her formidable rhetorical power. We are reminded of the words of Jeanette C. Lauer and Robert Lauer, who write in their book Fashion Power: The Meaning of Fashion in American Society (1981) that fashion is a key element in the "process of political staging oneself" and assists in increasing social desirability ${ }^{60}$ Therefore, Frau Goebbels' fashioning of the body specifically worked in strengthening her own charisma and social desirability whilst transferring her motherly aura to the violent symbols of the regime, ensuring that the reputation of the Nazi state remained commendable.

Also in 1936, Heinrich Hoffmann photographed Frau Goebbels just before her boarding of a plane to Greece. In the photo, she is seen talking to the Greek ambassador Alexander RizoRangabe (figure 2.5), an image that was published in the newspaper Das $12 \mathrm{Uhr}$ Blatt. Frau Goebbels wears a muted - probably grey - classic suit with a fur stole and a black hat. Even at this period, when suits were already popular for women, they continued to hold traditionally "masculine" connotations symbolizing respectability and seriousness. When connecting the suit (the signifier) with its connotation of masculinity and power in relation to the context it is being worn in (in discussion with an international actor), the sign reveals that this specific attire was used to reinforce the legitimacy and respectability of the party internationally. The era's suitswearing Hollywood actresses such as Marlene Dietrich projected sophistication, as Alison Lurie has shown and Frau Goebbels is, therefore, giving the Nazis a much-needed dose of missing sophistication. ${ }^{61}$ Whereas Hitler chose to wear his uniform as an image reinforcing his total domination of the nation, the first lady of the Reich wears varied fashions to extend the party's

\footnotetext{
${ }^{59}$ Klabunde, Magda Goebbels, 225.

60 Jeanette C. Lauer and Robert H. Lauer, Fashion Power: The Meaning of Fashion in American Society (Englewood Cliffs: Prentice Halls, 1981), 52.

${ }^{61}$ Lurie, The Language of Clothes, 29.
} 
authority, power and influence, through more subtle means, yet ultimately helping in the implementation and normalization of totalitarian methods.

Not only did her suit infuse the party with "masculine" respectability but it worked towards lifting her own status too. She is establishing a role for herself as a powerful working woman, while also embodying the ideals of motherhood. This dual identity Magda Goebbels played on worked rhetorically towards appealing to two types of German women in this crucial process of Nazifying Germany: the ambitious career and working woman and the traditional mother; or as Leila J. Rupp elaborates, the Nazi's fascination was felt amongst two opposite groups; conservative women "who sought confirmation of their worth as wives and mothers" and young, active women "who rejected the staid bourgeois life of the older generation." ${ }^{.62}$ It was to both that Magda Goebbels sartorial rhetoric appealed.

In the same year, in October 1936, Frau Goebbels was photographed at the official reception for the International Association of the Union of Writers and Composers at the Hotel Kaiserhof in Berlin (figure 2.6), a luxury hotel next to the Reichskanzlei. Various Nazi elite members, as well as the Italian propaganda minister Dino Alfieri and Dr. Fred C. Willis, the head of the Italy Division in the Reich Ministry of Propaganda, attended this event. Providing insight into an elite Nazi reception, this photo showcases Magda Goebbels wearing an off-the-shoulder metallic lamé gown with a twisted bust decorated with a brooch and a single row of pearls around her neck. The metallic lamé, which was used at that period in Hollywood movies to make a character stand out, was a symbol of lavish and opulent style. ${ }^{63}$ Paired with other signifiers that connoted luxury and wealth, such as the pearl necklace, the brooch and earrings, this attire

\footnotetext{
${ }^{62}$ Leila J. Rupp, “Mother of the 'Volk': The Image of Women in Nazi Ideology," Signs 3, no. 2 (1977): 379.

63 "If a female character needed to stand out a bit, but not to the extent of bugles and beads, the designer could use lamé.” Margaret J Bailey, Those Glorious Glamour Years (New York: Citadel Press, 1982), 24.
} 
signifies Hollywood regal glamour. This signification is further evidenced by the fact that her dress greatly resembles, in the material and in the off-the-shoulder neckline, a number worn by the "Platinum Blonde" actress Jean Harlow (1911-1937), one of Hollywood's greatest stars, in the musical movie Reckless from 1935 (figure 2.7). Recalling Barthes's assertion that signifying codes are intrinsically embedded in people's minds, a citizen of that era catching a glimpse of Frau Goebbels dress would have associated it with modern glamour. ${ }^{64}$ Frau Goebbels' appropriation of Hollywood style correlates to the fact that Hollywood movies were extremely popular in Nazi Germany and scholar Ben Urwand suggests that they "infused all aspects of German culture. ${ }^{.65}$ This appropriation is further reinforced in Frau Goebbels finger waves; Frau Goebbels' blonde locks, whilst in tune with "Aryan" ideology, were also prominent in Paris and Hollywood, a trend that scholars attribute to Hollywood actresses such as Carole Lombard and Jean Harlow. ${ }^{66}$ Like the Hollywood stars who provided "a modern and glamorous feminine imagery, offering gendered images of fantasy and desire, ${ }^{, 67}$ Magda Goebbels' embodiment of Hollywood's regal glamour positions her as a German celebrity with the aura of international prestige.

Conspicuous luxury is also on display in 1938 at the annual Day of National Solidarity for the Winter Relief, when photographer Heinz Fremcke captured Magda Goebbels at the event holding a bucket and collecting donations (figure 2.8). The Winter Relief program aimed at giving back to "deserving" German citizens. Through this program, the Nazis organized annually

\footnotetext{
64 "I have in front of me three different-colored lights (red, green, yellow). I have no need of language to understand that each of these signals has a different meaning (stop, go, caution): I simply need an apprenticeship period so that the meaning will come to be directly in situations where the signified is used." Barthes, The Fashion System, 29-30.

65 Ben Urwand, Collaboration: Hollywood's Pact with Hitler (Cambridge: The Belknap Press of Harvard University Press), 7.

${ }^{66}$ Fiell and Dirix, 1930s Fashion :The Definitive Sourcebook, 27.

${ }^{67}$ Leila Wimmer, "Modernity, Femininity and Hollywood Fashions: Women's Cinephilia in 1930s French fan Magazines," Film, Fashion \& Consumption 3, no. 1 (March 2014): 66.
} 
a Day of National Solidarity during which leading Nazi personalities would take on the streets to collect donations from citizens resulting in the gathering of large crowds. According to Thomas E. de Witt's study “The Struggle Against Winter and Cold: Winter Relief in Nazi Germany, 1933-1939," the event was purposely staged for maximum results because the presence of these elite members incited people to increase their donations.

In that photograph, Magda Goebbels is seen wearing a tweed coat with a long fur stole, a boater hat decorated with a ribbon, bows and a veil shielding her face, lipstick and earrings. If the veil was very popular at the period to embellish hats, it also conceals parts her face whilst drawing attention to it. ${ }^{68}$ As Valerie Steele writes: "Veils are used to cover and conceal yet at the same time drawing attention to some visual aspect of the wearer." The veil shielding her face focally points to how Frau Goebbels separated herself from the public, symbolizing her higher elite rank, as further evidenced by the fact that women surrounding her are not - at least from what is displayed in the photo - wearing one. The boater hat she is sporting in these photos is also similar to a model by Jean Patou published in the February 1939 edition of Vogue Paris (figure 2.9). The fact that Frau Goebbels was fashioning herself in line with the attires published in Vogue Paris symbolizes her sophisticated taste, which worked towards increasing her public charisma as she is also shown to serve her country and help the poor in line with National Socialist ideology. This is even more relevant when associating the signifier (the hat) and its connotation with the signified (the context); in 1938, as Germany grew closer to embark on World War II, fewer citizens had access to fashion extravagance. Her fur stole was another of these luxuries symbolizing her desire to exhibit her wealth and status. Indeed, the fur stole in the 1930s was "the most sought after accessory in Paris" especially used to visually signify one's

\footnotetext{
68 "Veils are used to cover and conceal yet at the same time drawing attention to some visual aspect of the wearer." Valerie Steele, Encyclopedia of Clothing and Fashion (Farmington Hills, Thomson Gale, 2005), 391.
} 
social rank because of its worth. ${ }^{69}$ This style greatly contrasts with the covers images of the 1937 and 1938 issues of NS-Frauen-Warte, which show mothers devoid of any conspicuous fashion or ornamentation, the women's only accessories being the babies and children (figures 2.10.a and 2.10.c). Both show natural faces and working garb, advancing a semiotic of extreme simplicity that ostensibly contradicts international sartorial trends. Yet for an important Nazi event, Frau Goebbels preferred to don a trendy attire similar to what was being worn in Paris.

Diana Crane reminds us that clothing "can be manipulated or reconstructed so as to enhance a person's sense of agency, ${ }^{, 70}$ and by openly showing off her personal agency through an attire that contradicted official propaganda, by 1938 Frau Goebbels' suggested the illusion of freedom in a regime in which individual and collective freedoms were ever more curtailed; it is interesting to view the expressions of the women close by, who observe the bucket with curiosity, reminding us of De Witt's description of the donation practice as a form of "extra-legal taxation" that Nazis used along with "intimidation to extract contributions." ${ }^{, 71}$ Frau Goebbels" fashionable attire glossed over the intimidation and pressure tactics. A big smile decorates her face and she positioned her body towards the camera ignoring the women who seem more interested in the bucket she is holding than in her.

Fabrice d'Almeida further suggests that the public display of a lavish lifestyle helped isolate the Nazi elite from the masses which, in turn, worked to "foster the illusion that all members of the Volk were working to create a surplus" conspicuously hinting at the success of

\footnotetext{
69 "The most sought after accessory in Paris was the fur stole, slipped over the head like a figure of eight, and worn with most daytime outfits. Throughout times of financial or political instability, status items such as fur are craved by fashionable women." Jane Mulvagh, Vogue History of The 20th Century Fashion (London: Viking 1988), 113. ${ }^{70}$ Crane, Fashion and its Social Agendas, 2.

${ }^{71}$ Thomas E. de Witt, "The Struggle Against Winter and Cold: Winter Relief in Nazi Germany, 1933-1939," Canadian Journal of History 12, no.3 (February 1978): 366.
} 
the regime and at the new prosperity the party could bring to Germany. ${ }^{72}$ The Nazis' political strategy was resting on the promise that they would extend luxury to every "Aryan" citizen persuading the nation into believing that the party was in good health, ${ }^{73}$ just like the healthy bodies they were promoting on the cover of the 1938 NS-Frauen Warte issues (figure 2.10.b). Joseph Goebbels understood the importance of getting support from the masses and was adept at appealing to those who remained outside "and therefore had no access to this small additional pleasure which the recognition and feeling of belonging to a privileged circle provided.",74 Adhering and supporting the party offered promises of social mobility, as symbolized by Frau Goebbels' glamour and luxurious attires. As Guenther writes: "Fashion also served to nurture the desires and dreams held by ordinary German women of consumption."75 Although in reality, the composition of the elite rarely changed and the population never obtained access to this privileged luxury, the illusion and promise were more important than ever, as their everyday lives became ever more disciplined and rationed as the regime embarked on a politics of expansion (claiming territory in eastern Europe) and war. ${ }^{76}$

This display of potent luxury strikingly comes to life in Hoffman's official photograph of Magda Goebbels, depicting her walking next to the Prince Paul of Yugoslavia, (figure 2.11) who visited Germany with his wife Olga as official guests for five days in June 1939. Part of their royal tour included an afternoon meal with Joseph and Magda Goebbels at the Goebbels' villa on Schwanenwerder Island in Berlin. Extensively covered in the media both in Germany and internationally - the New York Times reported in May 1939 the visit of the Yugoslavian royals to

\footnotetext{
72 Fabrice d'Almeida, "Luxury and Distinction Under National Socialism," in Pleasure and Power in Nazi Germany, ed. Pamela E. Swett, Corey Ross and Fabrice d'Almeida (Basingstoke: Palgrave Macmillan, 2011 ), 71.

${ }^{73}$ D'Almeida, "Luxury and Distinction Under National Socialism," 71.

74 D'Almeida, "Luxury and Distinction Under National Socialism," 72.

${ }^{75}$ Guenther, Nazi Chic?, 13.

${ }^{76}$ D’Almeida, “Luxury and Distinction Under National Socialism,” 71.
} 
Germany - this event was the topic of many photographs published in newspapers. One of these appeared in the Berliner Illustrierte Zeitung, presenting Magda Goebbels in a floor-length white dress decorated with voluminous puff shoulders, ruffles at the hem of the skirt, a cinched waist adorned with a belt, a tiered peter pan collar held together with a gem button. The cinched waist and exaggerated broad shoulders and low neckline align with the fashionable silhouette of the period as described by Charlotte Fiell and Emmanuelle Dirix in their book 1930s Fashion: The Definitive Sourcebook (2012). The overall design of the dress is very similar to a French Madeleine Vionnet dress seen in the June 1939 edition of Vogue Paris (figure 2.12), once again drawing parallels between Frau Goebbels' public style and Parisian fashion.

Frau Goebbels' dress looks strikingly similar to a white organdie gown worn by Hollywood actress Joan Crawford in the movie Letty Lyon in 1932 (figure 2.13). The silhouette and cut are almost the same, just like the voluminous sleeves, the ruffles at the hem of the skirt and even the colour, hinting at how Frau Goebbels wanted fashion herself as a glamorous, sophisticated, high elite lady. Moreover, in 1939 Europe, afternoon dresses were cut somewhere between below the knee and above the ankle whereas Magda dons a floor-length gown usually associated with evening wear, automatically making a statement of refinement and graciousness. This is further evidenced by observing Frau Goebbels' look in contrast with Princess Olga of Yugoslavia's gown. Other archival photos from the afternoon reveal the princess chose a calflength polka-dot dress with a tight waist and subtle emphasis on the shoulders (figure 2.14). On the other side, Frau Goebbels wore a much more ornamented floor-length number, evoking Hollywood's fashion, lending status and gloss to the Nazi party.

Considering how much the regime wanted to "impress foreigners with the grandeur and success of its ideas," as scholar Fabrice d'Almeida reminds us, elite members of the party were 
intent on infusing the regime with prestige. ${ }^{77}$ Society women like Magda Goebbels or royalty like the Prince and Princess of Yugoslavia "demonstrated, particularly where foreign opinion was concerned, that the Hitler movement was not made up of a band old strong-arm roughnecks." ${ }^{, 78}$ As Jonathan Petropoulos argues, this elite bolstered public support because when a high ranking society member was endorsing the party, it publicly heightened its reputation and gave the impression of great success. Fabrice d'Almeida similarly asserts in High Society in The Third Reich (2008), "success makes one acceptable." ${ }^{, 79} \mathrm{D}$ 'Almeida is onto something when he notes that the party wanted to be successful internationally and therefore used international fashion so they did not look ridiculous in the face of foreign visitors. ${ }^{80}$ People of high fashion acted as influencers, as he writes: "Life in high society was one of the channels for influencing the way foreigners looked on Germany." ${ }^{, 1}$ McDonald also says: "Dress in this sense can confer legitimacy upon its wearer, granting an image of power (so long as others view the message that way in the particular social context). ${ }^{982}$ Evidently, Frau Goebbels' luxurious looks worked rhetorically to show the party in a positive and successful light, both within the country and internationally.

Beyond conferring distinction and eminence by the cut, the materials, the ornamentation as well as the details and the colour of a dress can encode political messages and engage the political and social environment of the period. Magda Goebbels, who did not wear a white dress on her wedding to Joseph Goebbels as it was her second marriage, wore a conspicuous white dress in June 1939, on her meeting with the royals of Yugoslavia, only months away from

\footnotetext{
${ }^{77}$ Bleuel, Strength Through Joy: Sex and Society in Nazi Germany, 92.

${ }^{78}$ Meissner, Magda Goebbels: The First Lady of the Third Reich, 90.

${ }^{79}$ D'Almeida, High Society in the Third Reich, 27.

${ }^{80}$ D'Almeida, High Society in the Third Reich, 121.

${ }^{81}$ D'Almeida, High Society in the Third Reich, 173.

${ }^{82}$ McDonald, "Fascist Fashion: Dress, the State, and the Clothing Industry in the Third Reich," 37.
} 
Germany declaring a war that would eventually destroy the regime and kill millions all around the world ${ }^{83}$ Goebbels' ostensibly all-white dress reminds us of Nancy MacDonnell Smith statement in her book The Classic Ten: "A woman who dresses all in white tends to come across as fragile and delicate as a gardenia." ${ }^{, 44}$ Or, as Kimberly Wahl reminds readers in the 2017 book Colors in Fashion, white is collectively known as standing for innocence and purity. White is the international colour of peace and only a few months before Germany's engaging in the deadliest armed conflict of all time, Frau Goebbels' display of white acts as a rhetorical cover of the Nazis' intentions: signalling peace while planning for war and accelerating the extermination of Jews in Auschwitz in Poland. In the end, Frau Goebbels' embodiment of white helped whitewash the brutality and violence of the Nazi regime and one cannot help but make the connection with Frau Goebbels sartorial choices four years later, on the night of May 1st, 1945, when she administered lethal poison to her six children aged five to twelve, before taking her own life. Each child's name started with "H" commemorative of Hitler and each was doomed to die a day after the Führer's suicide. That night, Frau Goebbels dressed each child in a white nightgown and decorated the girls' hair with ribbons before murdering them. The chilling symbolism of the colour white and the act are interlinked to complement the actions of another fashionable Nazi woman, who had committed suicide a day before and whose role was certainly different, though ultimately, disturbingly compatible and consistent with that of Magda Goebbels. We now turn to the sartorial legacy of Eva Anna Paula Hitler, née Braun.

\footnotetext{
${ }^{83}$ Lurie, The Language of Clothes, 182.

${ }^{84}$ Nancy MacDonell Smith, The Classic Ten: The True Story of the Little Black Dress and Nine Other Fashion Favorites (London: Penguin Books, 2003), 88.
} 


\section{CHAPTER 3: Case Study 2: Eva Braun's Wardrobe}

Considering the extreme state of secrecy that characterized Eva Braun's short life, the conditions under which her videos, photos, diary and assets were preserved and survived the end of the war provide insight into Braun's life and priorities. Hitler destroyed most evidence of his private life before committing suicide, but Eva Braun's approach was different. In the last few days before the capitulation of Germany, she "entrusted [her assets] for safekeeping to the SS Oberführer Wilhem Spacil." ${ }^{\prime 5}$ Spacil took them to Austria where he turned them over to the SS Hauptsturmführer Franz Konrad. American agents of the Counter Intelligence Corps then seized these assets from Konrad in August 1945. This context reveals Braun's intent to salvage some parts of her life, including imagery. Braun's biographer Heike B. Görtemaker alleges that just a few days before taking her own life, Braun requested that her sister Gretl destroy all business papers - especially her fashion designer bills - but that she store and protect her letters from the Führer as well as copies of her responses (still, these letters to this day have never been found). ${ }^{86}$ Braun's biographer Nerin E. Gun asserts that Gretl Braun Fegelein hid her sister's belongings (including photo albums, films, letters and jewelry) at her husband's Hermann Fegelein's castle (Schloss Fischer at Zell-am-See in Austria), where an American officer pretending to be a German refugee later found them; ${ }^{87}$ Görtemaker, in contrast, suggests that the thirty-three photo albums were found in Eva Braun's house on Wasserburger Strasse in Munich. ${ }^{88}$ Regardless of the actual circumstances of discovery, days before committing suicide, Eva Braun's letters to her sister Gretl expose her concern "about her image for posterity." ${ }^{89}$ As the surviving visual

\footnotetext{
${ }^{85}$ Disposition of Silverware and Effects Described as Property of Eva Braun, 5 March 1948.

${ }^{86}$ Görtemaker, Eva Braun: Life With Hitler, 86.

${ }^{87}$ Nerin E. Gun, Eva Braun: Hitler's Mistress (New York: Meredith Press, 1968), 289.

${ }^{88}$ Görtemaker, Eva Braun: Life With Hitler, 164.

${ }^{89}$ Görtemaker, Eva Braun: Life With Hitler, 86.
} 
material documents, Eva Braun had been engaged in a revealing process of identity construction to ensure that the world would know about her, about her relationship with Hitler and about her role in the Third Reich.

Braun's diary also tackles an important part of her existence, one that is not explicitly visible in imagery. Hitler's mistress' life was punctuated with loneliness, two suicide attempts (before her actual suicide in 1945) and despair. This is nowhere better represented than in Fräulein Braun's private diary, enclosing eleven entries between February 6th, 1935 and March 26th, 1935. In this concise, yet powerful, archival piece, Braun expresses her constant state of unhappiness and loneliness, penning on February 6th, 1935: "If I only had a dog, then I wouldn't be quite so alone.. ${ }^{90}$ Planning her suicide on May $26^{\text {th }}, 1935$, she blames Hitler's absence and negligence for the actions she is about to commit: "If I don't get an answer by ten tonight, I'll take my twenty-five pills and lie down peacefully. Is it a sign of the terrific love of which he assures me, that he hasn't spoken a kind word to me three months? Agreed that he's been busy with political problems, but have not things eased off?" ${ }^{\text {91 }}$ Whilst this diary solely chronicles a few months of the relationship, biographers agree that this loneliness and lack attention from Hitler continued throughout her relationship with the dictator. "As the years passed, Eva changed. She became restless, bored and ill," as her biographer Lambert writes in The Lost Life of Eva Braun, ${ }^{92}$

In contrast to the suicidal ideation evident on the pages of her diary, she used fashion and the camera to stage a very different identity, constructing what looks like fantasy pictures. In 1937, Heinrich Hoffmann photographed her at the Berghof: in this idyll of a traditional family

\footnotetext{
${ }^{90}$ Braun, "Eva Braun's Diary with English Translation," February 6th, 1935, 1.

${ }^{91}$ Braun, "Eva Braun's Diary With English Translation," May 26th, 1935, 4.

${ }^{92}$ Lambert, The Lost Life of Eva Braun, 172.
} 
photo, Eva Braun sits opposite Hitler in front of a large wall hanging, the pair equally focused on young Uschi, her friend Herta Schneider's 4 or 5-year-old daughter (figure 3.1). Braun wears a polka-dot dress with a white shirt collar, white high heeled shoes and a bracelet. The choice of the dotted pattern is interesting as it symbolizes playfulness. Stemming from "a craze for polka music that swept Europe from the 1830s to 1860 s, ${ }^{, 93}$ polka-dots are found in images of humoristic characters, including the 1930s Minnie Mouse and in clowns costumes, ${ }^{94}$ suggesting a strategy to uplift Braun's mood and divert attention away from the less-than-idyllic reality of her existence. The dotted patterns were also often used at the period in children's products and clothes. ${ }^{95}$ These neotonous elements are further manifested in the composition of the fashion image as Braun's white collar and white shoes directly correlate with the immaculate white dress of the child. Braun's sartorial strategy sets her apart from Hitler's drab suit. As Barthes writes, "fashion presents the woman as a representation, in such a way that a simple attribute of the person, spoken in the form of an adjective, actually absorbs this person's entire being. ${ }^{96}$ In other words, the boisterous and youthful polka-dot dress transferred the qualities of the garments to build the persona of a joyful and happy woman-child, perhaps also the role that Hitler liked to see her assume in his presence. As her biographer corroborates: "In thousands of photographs and hours of home movies Eva presents herself as she wanted to be seen: a golden girl, spinning, giddy."

\footnotetext{
93 Jude Stewart, Patternalia: An Unconventional History of Polka Dots, Stripes, Plaid, Camouflage \& Other Graphic Patterns (New York: Bloomsbury, 2015), 23.

94 “[...] in the joyful movements of the polka." Vogue Paris, May 1922, 42.

95 "Polka dots enjoyed a resurgence - one particularly female, yet oddly ambiguous -- in early twentieth-century America. Clean and simple in its machine-printed version, the pattern exuded a lively wholesomeness appropriate for children and popular on bedsheets, bassinets and nightgowns." Stewart, Patternalia: An Unconventional History of Polka Dots, 25.

${ }^{96}$ Barthes, The Fashion System, 254.
} 
Capturing Hitler with his mistress in an everyday, informal moment, the photo is also profoundly staged in evoking the family intimacy that was missing from her life. The fashion display gains further meaning when considered in relation with the signified: picturing herself beside one of the world's most brutal and merciless dictators in a representation of a family-like interaction. Hitler wears a big happy smile on his face as his attention is focused on little Uschi. While he sits enveloped by his chair, as if sitting in a throne, he faces Eva but is really sentimentally focused on the child; meanwhile, Eva sits on a chair sideways, her body turned away from Hitler to front the camera, with only her face- frowning and serious - turned to face the child. It is a strange photograph revealing tensions between Eva's staged playfulness and self-protectiveness, sitting legs crossed, and playing to the camera more than playing to Hitler.

A few years later, her private motion pictures from 1939-1940 further reveal Braun's use of fashion and technology to construct a fictional picture driven by a desire for a private and public identity that was withheld from her. In one segment, Braun has donned a Tuscan pink dress decorated with an abstract pattern of beige (figure 3.2). The sun casts strong shadows doubling her silhouette behind her and her skin glistens, down the V neckline. She is holding an overly large bouquet of flowers with pink and beige roses that mirror the dress. Her posing emphasizes that she is staging herself for the camera, like a bride, holding this huge bouquet for an imaginary wedding. This display of colours reminds us of Helen Varley's argument, in the book Colour (1980) that strong and vibrant hues, such as red, were morale-boosters during the early days of the war. ${ }^{97}$ Roach and Eicher similarly suggest that individuals sometimes deliberately choose to wear joyful and colourful clothing as a way to combat negative

${ }^{97}$ Helen Varley ed., Colour (London: Marshall Editions Limited, 1980), 138, 122. 
emotions. ${ }^{98}$ The vibrant hue is also connected with seduction, desire and attraction. ${ }^{99}$ Through the dress' flirtatious colour, which is repeated in the flowers and on Braun's lips, Eva is engaging in a seductive performance playing to an audience, possibly her posthumous public, but also Hitler himself who categorically refused to marry her (up until the very end of his life), claiming to be married to the German people.

Indeed, the historian Brigitte Hamann highlights in the 1999 book Hitler's Vienna: A Portrait of the Tyrant as a Young Man that Hitler's political style copied that of the charismatic anti-Semitic mayor of Vienna, Karl Lueger, by building his power on the adoration women had for him. "Hitler did witness in Vienna women's euphoric, even hysterical sacrificial acts for a charismatic politician. Later on, he was to manage just as brilliantly to assign women this very same part so they would serve his political purposes. ${ }^{100}$ Hitler thought that if he committed to a woman, his idealized status would be impoverished as women would fall out of love with him, threatening his cult of personality. ${ }^{101}$ In turn, Braun used fashion as a tool of seduction both to charm a fictional public and a distant Hitler, who had no intention of having a family with her or making her the first lady of Nazi Germany. Eva Braun was left with the sidelined position of the mistress, ensuring her vulnerability and personal dependence on Hitler. This gendered use of fashion as a seductive tool reminds of us of Hans Peter Bleuel's study which highlights how the party arranged socials meetings and dances to help men meet women. The Women's Associations and BdM would pre-select girls to attend these events, but they did not attend in uniforms, "but in attractive afternoon dresses or regional costumes."102 Moreover, in 1929, Reich

\footnotetext{
${ }^{98}$ Roach and Eicher, "The Language of Personal Adornment," 110.

99 Michel Pastoureau and Jody Gladding, Red: The History of a Color (Princeton: Princeton University Press, 2017), 187.

${ }^{100}$ Lambert, The Lost Life of Eva Braun, 376.

${ }^{101}$ Görtemaker, Eva Braun: Life With Hitler, 162-263.

102 Bleuel, Strength Through Joy, 169.
} 
Propaganda Minister Joseph Goebbels wrote that "the mission of a woman is to be beautiful and to bring children into the world... The female bird pretties herself for her mate and hatches the eggs for him. In exchange, the mate takes care of gathering the food and stands guard and wards off the enemy." ${ }^{103}$ Alluding to the use of beauty and fashion as a seductive technique to attract male partners, the party understood that beauty and fashion could help with their birth rate goals - but the Nazi's favourite role of mother was denied to Eva Braun, who used fashion, accessories and a camera to construct a bridal identity that would later become a surreal reality and death sentence.

As Barthes reminds us, the layering of fashion styles provides intricate paradoxes which offer "the illusion of a quasi-infinite richness of the person." 104 One image that epitomizes Eva Braun's ambivalent role dates from 1942 when she was photographed on the terrace at the Berghof surrounded by four men in uniforms (figure 3.3). While the men around her have not been identified, their presence at Hitler's private villa at the Berghof as well as their military garb divulge their status as Nazi officials or orderlies. The composition directs the attention to her as she is the only woman and she is positioned at the center, having familiarly taken the arm of one of the officers while talking with two of the others. Braun is wearing a calf-length fur coat layered over a dress with platform shoes and a necklace. The fur coat symbolizes her status because of its monetary value, a value further boosted in 1942 as the rations became more and more systematic to sustain the war efforts. ${ }^{105}$ Her prominent necklace contrasts with her dress, reminding us of scholar Alison Lurie's assertion that wearing jewelry is like wearing money. ${ }^{106}$ Her attire and familiar pairing with one of the officers reveals her aspirational path: her desire to

\footnotetext{
103 Guenther, "Fashioning Women in The Third Reich," 91-142.

104 Barthes, The Fashion System, 254.

105 Fiell and Dirix, 1930s Fashion: The Definitive Sourcebook, 16.

${ }^{106}$ Lurie, The Language of Clothes, 128.
} 
belong within this community of German military men, as a first lady who helps entertain the hardworking Wehrmacht during increasingly difficult times. With her attire drawing similarities to a fashion photograph published in the December 1939 edition of Vogue Paris (figure 3.4), she enacts the fantasy of playing in the same league as powerful women like Magda Goebbels or Emmy Göring. The latter was an actress who had married prominent Nazi Hermann Göring in 1935 with Hitler as a witness. Emmy made public appearances at state functions, the same from which Braun was categorically excluded leading Frau Göring to treat Eva Braun with disrespect. Beyond her fur and jewelry, Braun also makes another, perhaps more subtle, statement about her status through her lack of a hat and footwear. Braun wore opened platform shoes in the cold winter snowy land pointing to her elite and prosperous lifestyle. This choice of footwear visually symbolizes the type of comfortable lifestyle she enjoyed, where she was required to do no physical work, relying on servants and orderlies, so she could afford to wear impractical summer shoes in the snow. Clearly, the role staged for posterity is that of the mistress of Berghof, where she receives visitors, sharing with them the exceptional vista that stretches behind them. Overall, the addition of the various signifiers (the fur, the jewelry, the shoes, the men surrounding her) and their social codes connects to the context of the image (the snowy Alps that were Hitler's retreat) produces a clear and strong meaning: Braun was staging herself aspirationally as an elite lady, aiming at lifting her lowly social rank and assume her role as the Nazi’s first lady.

This desire to be remembered as a high ranking woman in the Nazi echelon also makes her deeply complicit, as evidenced in the collection of assets she entrusted her sister for protection before committing suicide. In 1945, the Washington Post reported that American Intelligence officers had found Braun's treasure chest in which they discovered thousands of 
dollars in American bills as well as a brooch set with 50 diamonds and a silverware set bearing the royal emblem of the Polish Crown, suggesting that she was in possession of stolen goods confiscated in Poland. ${ }^{107}$ After Nazis invaded Poland in 1939, it "was no longer recognized as a nation, its collections were there for the taking" and they looted the country of most of its treasures, cultural heritage that ended in Nazi hands. ${ }^{108}$ As we juxtapose these images of looted assets in Eva Braun's possession with the photographs of playful and innocent polka dots dresses we are reminded of a photograph of another young girl: Gudrun Himmler (1929-2018), the daughter of Heinrich Himmler, architect of the Final Solution that planned the extermination of the Jews, who poses affectionately with her father as a 10- or 12-year old, wearing her fashionable polka dot dress, her arms wrapped around her father. After the fall of the Reich, with the dark reality of Nazi atrocities coming prominently to light, Gudrun nonetheless continued to defend her father and throughout her long life supported Nazi sympathizers.

It is clear that Braun forged an irrevocable bond with Hitler, a paranoid man with whom it was dangerous to forge any kind of friendship. A 1942 photo depicts Eva Braun on the terrace of the Berghof sitting behind the dictator, both observing photographs that Heinrich Hoffmann (who is pictured standing on the right) has brought along (figure 3.5). This photo is remarkably relevant to the discussion because it includes Braun and Hitler as a couple, performing their bond and establishing her identity as Hitler's secret spouse for posterity. Rhetorically, Hitler occupies the position of control in this composition as he is on the front plan and has physical access to the photos, a stance that symbolizes his power. Yet Braun has strategically staged herself behind

\footnotetext{
107 "Pictures of Mysterious Baby Found in Eva Braun Treasures," The Washington Post, November 16, 1945.

${ }^{108}$ Lynn H. Nicholas, The Rape of Europa: The Fate of Europe's Treasures in the Third Reich and the Second World War (New York: Knopf, 1994), 65.
} 
him, but on a higher level and this elevated position reinforces her powerful role as the putative partner supporting the leader.

Braun's attire enhances the meaning of this composition as she is wearing a dress with some kind of fabric bow detail on the bust with a blazer. The blazer in the 1930s symbolized "masculinity" because it "exaggerated the male physique, squaring shoulders and narrowing hips through [...] padding and tailoring." ${ }^{, 109}$ Braun's blazer is placed almost like a repetition of Hitler's jacket, their proximity and similar shapes connoting it with power and authority, while making her role also slightly ambivalent, as to an outsider she might be seen as professional secretary of sorts. At the same time, Braun is not wearing the blazer, it is just resting on her shoulders, a fashion statement that in the manner of her summer footwear in the snow hints at her informal or special status. This type of fashioning of the body leaves no space for movement and is not practical for those who need to perform work and tasks. Therefore, these various connected signifiers reveal that Braun used fashion strategically to stage a visual rhetoric designed not only to increase her status but also to make a statement about her considerable role in the regime. Braun was borrowing from men's wardrobe to fashion herself in a way that is very different from how she is often represented in biographies, which typically describe her as a woman who had very little freedom within her relationship with the totalitarian leader. For example, the journalist Guido Knopp in his book Hitler's Women (2003) argues that Hitler disciplined Braun by forcing her to stay hidden in her room when an important visitor stopped by the Berghof, dictating the hairstyle she should sport and constantly treating her with authoritative manners. And yet, the visual evidence shows that she participated in wanting to be remembered as a key member of the Nazi elite, not as a hidden woman without any freedom or power.

\footnotetext{
${ }^{109}$ Monica M. Moore and Gwyneth I. Williams, "No Jacket Required: Academic Women and the Problem of the Blazer," Fashion, Style \& Popular Culture 1, no. 3 (2014): 361.
} 
By 1942, when this image was captured, the Final Solution had implemented the concentration camps as Germany accelerated the annihilation of Jews at a mass scale.

Conveniently, Braun had little interest in political activity, as historian Angela Lambert writes of Hitler's mistress: "[she] was never a member of the Nazi party, hated political conversations and debate and treated all her associations with National Socialists as personal friendships." $" 110$ Nonetheless, she was fully aware of the existence of the concentration camps and even warned her considerably more critical sister Ilse that if Hitler sent Ilse to a concentration camp, Eva Braun would not make an effort to get her sister out. ${ }^{111}$ Therefore, these self-constructions also give profound insight into the depth of Eva Braun's immersion in Nazi destructive and selfdestructive ideology.

This inconsistency and paradox of giddy girl and influential aspirant to the Führer's wife is exemplified in a photograph from 1944 (figure 3.6) which shows Eva Braun in conversation with Martin Bormann (1900-1945). Bormann was one of the most prominent Nazi officials of the Third Reich, serving as the Chief of Nazi Party Chancellery and Hitler's Private Secretary, who determined who was allowed access to Hitler. In his role, he was deeply involved in the regime's anti-Semitic persecutions, its slave labour program in the occupied East and he also helped push Germany's aggressive push toward war. In that photo, Eva Braun is shown wearing a floral dress with a cinched waist and puff sleeves, donning sunglasses; in her hand, in the immediate foreground of the image, she carries what at first glance looks like a purse but is really a camera. The camera's lens is turned sideways, away from the Nazi perpetrator, just as Eva's gaze was turned away from the atrocities of the Reich, some of which no doubt were

\footnotetext{
${ }^{110}$ Lambert, The Lost Life of Eva Braun, 169-170.

111 "On one occasion, Ilse, who never held back her criticism even when at the Berghof, was warned by her sister: 'If the Führer puts you in a concentration camp, I will not come to get you!'” Lambert, The Lost Life of Eva Braun, 169-170.
} 
discussed in the privacy of Berghof. Looking at this photograph today, her dress, with its floral pattern and ruched shoulders along with her dark glasses and selective camera, work like Barthes' punctum: the camera unsettles and gives insight into her complicity. She listens to one of the regime's henchmen, her face neutral, her mask intact. By 1944, Nazi leaders like Bormann had to confront serious troubles: Germany had suffered serious defeats in Belarus and Rome had been lost to the Allied Forces. In the photo, Bormann's face is serious, his eyes shadowed and inscrutable. And so is Eva Braun's, her fashion garb securing her composure and appearance of normalcy amidst the chaos caused by the Nazi regime. That she kept this compromising photograph, ensuring it was archived and preserved, is telling of her own view of herself within the Nazi reign where the formidable Bormann would be seen talking to her seriously, perhaps even conspiratorially.

The depth of Eva Braun's implication in Hitler's regime of violence and terror is corroborated by her final act. In April 1945, when the Russian army was moving toward Berlin, when the Third Reich was crumbling and Hitler's supporters expected a miracle waiting for the Führer's leadership, Eva Braun made her decision. She could have fled the bunker with her sister; she could have embarked on a new life beyond the Nazi regime and atoned for her own complicity. Instead, she contacted Berlin designer Annemarie Heise - who counted Eva Braun as a regular client - with a last-minute request for an elegant gown that would serve as Braun's wedding attire, though in the chaos of the war, the dress never made it to the bunker. ${ }^{12}$ Biographers assert that Braun wore an elegant haute couture black silk taffeta dress with a full skirt and high neck that she paired with a gold bracelet set with tourmalines, a diamond watch, a

${ }^{112}$ Görtemaker, Eva Braun: Life With Hitler, 86. 
topaz pendant and a brooch pinned in her hair ${ }^{113}$ - with Italian-made Ferragamo suede shoes. ${ }^{114}$

The black hue of the dress, instead of the usual white reflected the ambivalence of her situation:

Nazi Germany falling and her own death imminent.

A few days before committing suicide in 1945, as the British Captain Robert Work's interview with one of the last person to leave the bunker revealed, Hitler's mistress spent most of her time applying nail varnish, changing her clothes and partaking in various "feminine" tasks. She wrote letters to her sisters discussing mundane topics such as the price a tailoress charged her for a blouse, but also wrote farewell letters. ${ }^{115}$ If her black wedding dress hints at the sombre mood in the bunker, her actions suggest that Braun used fashion to escape reality, to create a sense of control in a chaotic world and to distract herself from the implosion of the Nazi regime. Her final actions return us to the earlier diary entry of February 11th, 1935, when Hitler did not buy her a gift (or at least the gift she wanted for her birthday) and so she bought herself jewelry to make herself happy. ${ }^{116}$ According to Hitler's private secretary Traudl Junge, who was present in the Bunker during the final days, Braun continued the fiction of normality, "showing off a parade of elegant clothes" during dinners at the Obersalzberg, never wearing the same dress twice and avoiding repeating the same outfit both for lunch and dinner, changing in between. ${ }^{117}$ Sometimes, she even changed outfits in the middle of a party; in April 1944, Junge noticed that Braun left a party only to return wearing a different dress, one made of silvery blue brocade. ${ }^{118}$

\footnotetext{
113 Gun, Eva Braun: Hitler's Mistress, 267.

114 Guenther, Nazi Chic?, 203-264

115 Sigmund, Women of the Third Reich, 176.

116 "He was just here, but no dog and no cupboard. He didn't even ask me whether I had a birthday wish. So now I bought myself some jewelry. A necklace, earrings and a ring to match for fifty marks. Everything very pretty. I hope he likes it. If not he may buy me something himself." Braun, "Eva Braun's Diary with English Translation,"

February 11th, 1935, 1.

${ }^{117}$ Traudl Junge, "My Time with Adolf Hitler," written in 1947, in Until the Final Hour: Hitler's Last Secretary, ed. Melissa Müller, trans. Anthea Bell (London: Weidenfeld \& Nicolson, 2003), 72.

118 Junge, "My Time with Adolf Hitler," 159.
} 
Historian Anna Maria Sigmund's observation that Braun worked in the manners of an archivist when it came to her clothes is extremely telling: keeping a file of everything she bought, its price along with a comment on how to accessorize it. ${ }^{119}$ This archival impulse mirrors that of Nazi Germany.

This investment in fashion as a pleasure and escape but also as a way of ordering a chaotic life amidst the Nazi horror reminds us of S. Jonathan Wiesen's argument that pleasure was a tool used by the regime to compensate for the numerous sacrifices it was imposing on the population. ${ }^{120}$ The party "understood that the morale of the population was dependent on simple pleasures like smoking." ${ }^{121}$ Purchasing goods granted consumer gratification as well as a distraction from the problems and insecurities arising from living within a totalitarian regime. Victoria Rust similarly argues that fashion and cinema allowed some sort of tolerated cultural expression which was used as a way to “accommodate its (female) citizens' fantasies and desires and not to alienate them from the regime."122 Solely asking the population for sacrifices would have possibly led to rebellions. Biographers Nerin E. Gun and Angela Lambert suggest that Hitler likewise tolerated Braun's fashion breaches as a way to ensure a relation of dominance and dependence with her just as he cultivated with the rest of the population. By the time she was in the bunker with Hitler, Braun had been fully Nazified, a process that for her was facilitated by fashion and her ability to archive herself and construct herself as a first lady of the regime. This

\footnotetext{
119 Sigmund, Women of the Third Reich, 167.

120 " From the moment it came to power, the National Socialist leadership faced the challenge of squaring its desire for self-sacrifice and communal thinking with the reality that people experienced desires, needs and pleasure as individuals. If the Nazis wanted to motivate people to build a racial utopia, they understood that they could not simply negate the forms of individual gratification available in other political contexts." S. Jonathan Wiesen, "Driving, Shopping and Smoking: the Society for Consumer Research and the Politics of Pleasure in Nazi Germany," in Pleasure and Power in Nazi Germany, ed. Pamela E. Swett, Corey Ross and Fabrice d'Almeida (Basingstoke: Palgrave Macmillan, 2011), 24.

${ }^{121}$ Wiesen "Driving, Shopping and Smoking," 27.

122 Rust, "Fashioning Women Under Totalitarian Regimes," 278.
} 
explains why she used fashion to distract herself, to stay calm and on course at the side of Hitler when Germany was losing the war. In her final act, like Frau Goebbels poisoning her children, she made a choice, set on ensuring that her images and photos would be preserved after the war, fashioning herself as Hitler's wife. Being Hitler's wife for 40 hours was preferable to surviving the war and starting life anew. 


\section{CONCLUSION}

As this analysis of Magda Goebbels' and Eva Braun's rhetorical fashion highlights, garments within the context of a totalitarian regime provide essential insight into the complex political, social and psychological functioning of fascism. As documented in this MRP, fashion works a mode of propaganda; even when contradicting official propagandistic representations of sartorial simplicity, the two women's fashion displays engaged in the political environment and supported the goals of the state. This is further advanced by the fact that Hitler leaned immensely on the way he presented himself and relied on public spectacle and on a staged identity to ensure his appeal which hints at the fact that he understood the potent tool fashion represented. ${ }^{123}$ The dictator is said to have stated: "Lift a finger against beauty culture and you make an enemy of [women]."124 The regime needed the women's support on several fronts, notably in their role as mothers given the importance of increasing the birth rate in order to achieve their ideological goals of a pure 'Aryan' nation and, more pragmatically, to feed the aggressive Nazi war machine.

If fashion was evidently used (and tolerated) by the Nazis because it allowed them to continuously reinforce their total domination, it also highlights key problematics within the National Socialist ideologies. As historian Irene Guenther argues, Magda Goebbels, for example, continued to shop at Jewish designers all up until official closures forced her to stop while Nazi officials based in Paris during the war would obtain Parisian garments and accessories for their wives. ${ }^{125}$ Nazi officials avoided commenting on fashion, never actually defining what an official German fashion would look like because they were so many contradictions inherent to the

123 Homberger and Bradley, "Nazi Dress: Hitler's Storm Troopers and Appearance Management, 1921-1933,” 184.

124 Bleuel, Strength Through Joy: Sex and Society in Nazi Germany, 83.

125 Guenther, Nazi Chic?, 212. 
ideology. Indeed, Hitler "refused to take a public stance on the topic" arguably because he was constantly torn between official morals and the political interest in allowing women to wear whatever they wanted. ${ }^{126}$ It is noteworthy that throughout the reign of the National Socialist party, the NS-Frauen-Warte, a biweekly anti-intellectual Nazi periodical for women, which included sewing patterns and promoted the National Socialist Women's League, continued to publish images of "Parisian" fashion, contradicting ideology in a magazine that itself worked as propaganda. If the Nazi regime murdered millions of people for simple expression of identity, Nathan Stoltzfus advances that Hitler was less harsh when it came to "Aryan" Germans who could be made docile through more subtle ways of persuasion than the use of brute terror and violence.

Even though the dirndl found favour even with Eva Braun, who can be seen in one of her videos plucking flowers adorned in this traditional Bavarian garment, the Nazi regime was never able to fashion women fully into their ideological vision of German-born dresses any more than they were able to create an Aryan nation. Still, Magda Goebbels and Eva Braun were fully invested in the Nazi movement so much that they committed suicide alongside the movement's top leaders. Their complicity leads up to these final acts. Frau Goebbels' fashion became a way of communicating with the public inside and outside the country, strategically softening and glamourizing the brute terror of the regime. Fashion rhetorically permitted public statements about the regime while manipulating citizens into complying with the state. Positioning her carefully selected attires in calculated visual compositions that circulated through the mass media, Goebbels used fashion to display illusionary normality and freedom as well as to add prestige and notoriety to the murderous state, strategies that all worked towards ensuring people

${ }^{126}$ Guenther, Nazi Chic?, 140. 
would obey the regime. Both women also made statements about their own roles within the regime. For example, by wearing suits, Frau Goebbels openly contradicted the Nazi ideological place of women and was constructing her identity as a strong, working woman. This further highlights the contradictory nature of Nazi ideology.

As the hidden and unofficial mistress, Eva Braun was admittedly more vulnerable, but she clearly had aspirations toward assuming her role as first lady beside Hitler. Fashion facilitated her aspiration to holding a prominent status. Isolated in her golden cage, Eva Braun was also manipulating visual technology and fashion to construct her own personal paradoxical identity for the Nazi present and posterity, ensuring that she would be remembered for her longterm role as the companion of Hitler, while also projecting the aura of an innocent, fun and giddy woman who conveniently absolved herself from the crimes of the regime. But as the evidence of their myriad of fashion images shows, both women had fully internalized the violent logic of the regime, which led them both to commit suicide and also led Goebbels to murder her children, revealing the perverted darkness underneath the cult of her white and always impeccably elegant attire. Ultimately, the fashion worn by Eva Braun and Madga Goebbels gives insight into the seesaw of seduction and destruction of the regime with the women's clothed bodies exposing their self-destructive Nazification. 


\section{FIGURES}

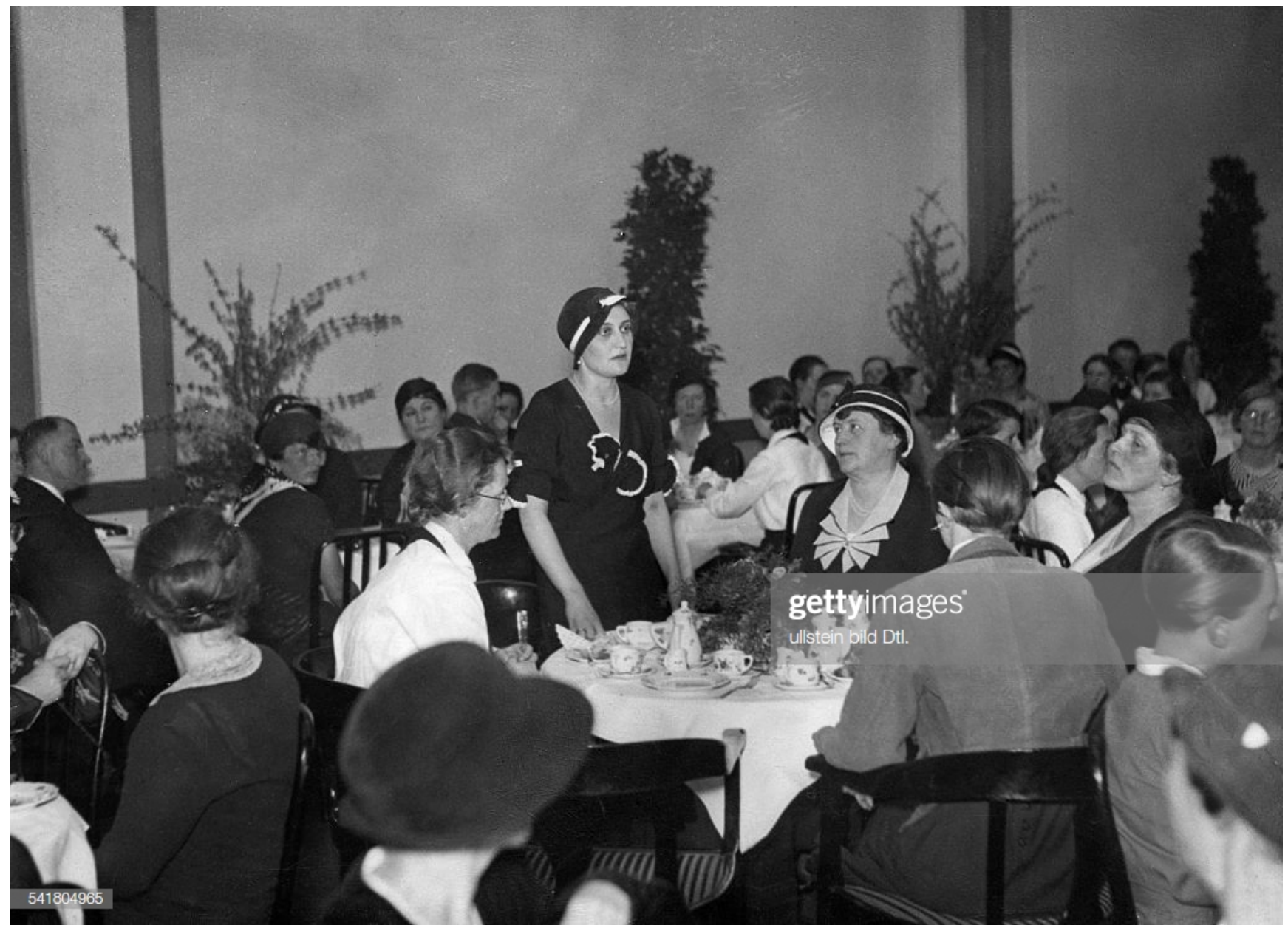

Figure 2.1: Robert Sennecke, Magda Goebbels at the opening of the exhibition "Die Frau" in Berlin, 1933. Photograph. Ullstein Bild via Getty Images, Berlin, https://www.gettyimages.fr/detail/photo-d'actualit\%C3\%A9/magda-geobbels1901-1945-wife-ofjoseph-goebbels-photo-dactualit\%C3\%A9/541804965 


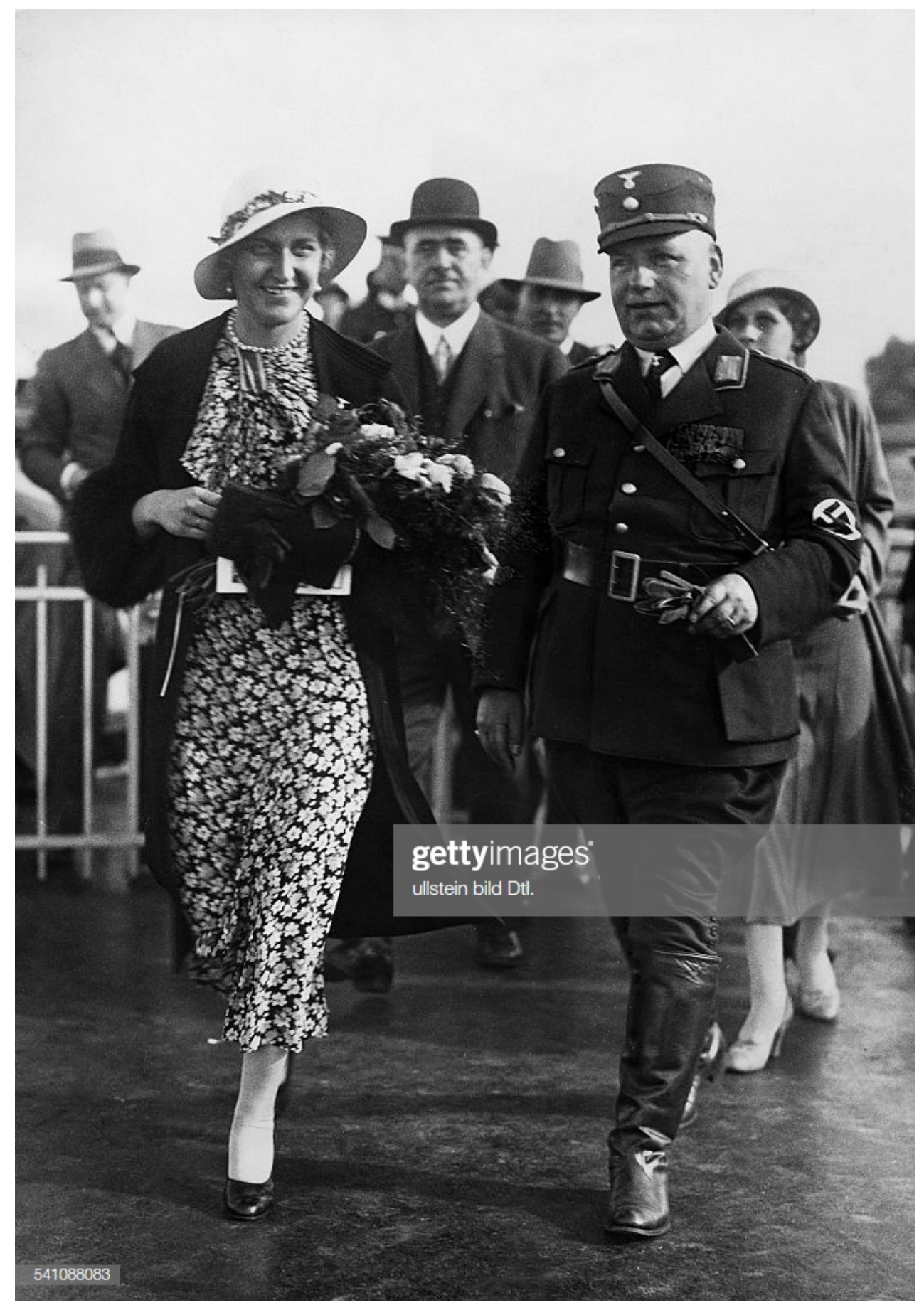

Figure 2.2: Magda Goebbels with Dr. Raeke at a derby match in Hamburg, 1933. Photograph. Ullstein Bild via Getty Images, Berlin, https:/www.gettyimages.fr/detail/photod'actualit\%C3\%A9/magda-goebbels-mit-dr-raeke-als-vertreterdes-photodactualit $\%$ C3\%A9/541088083 


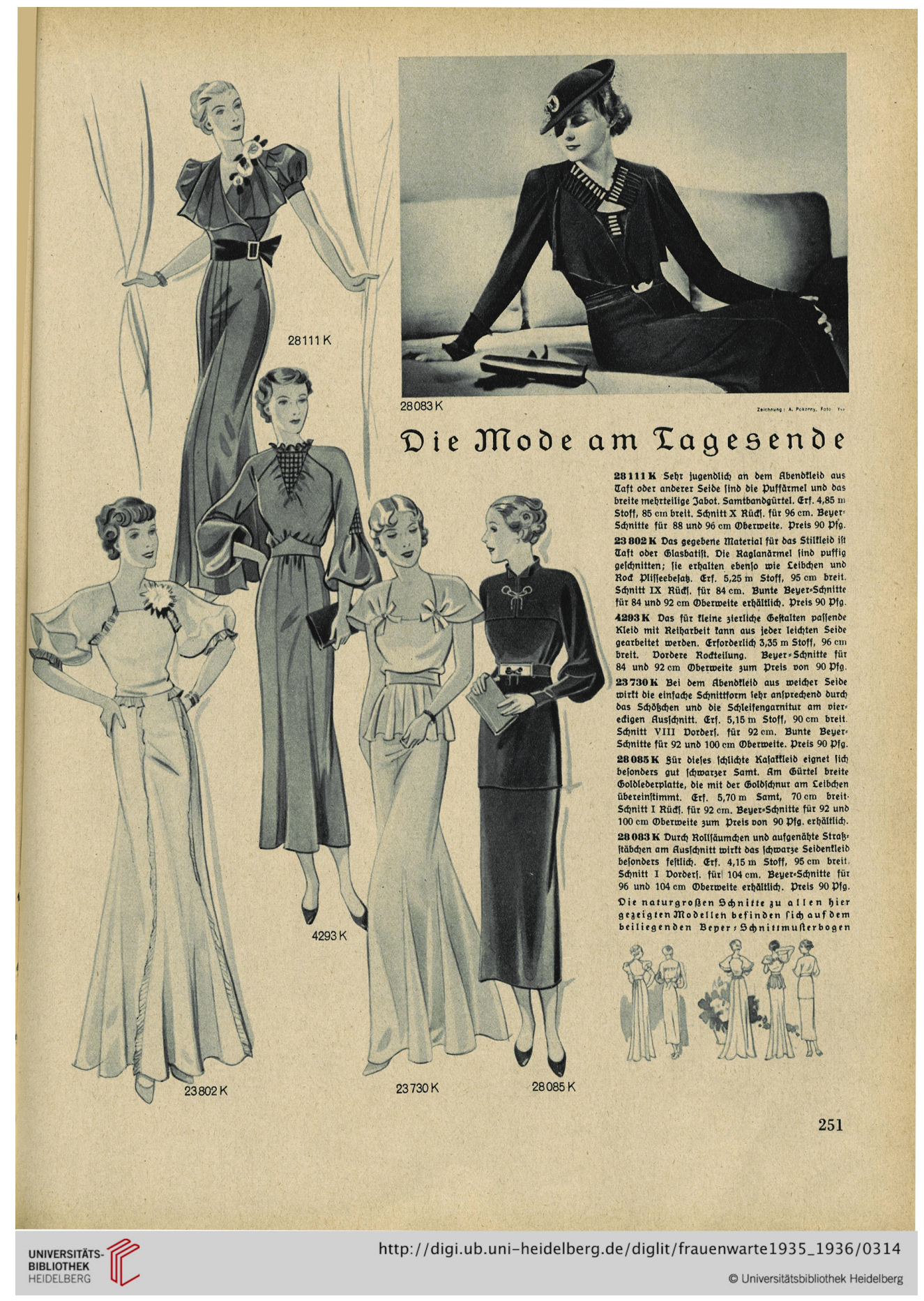

Figure 2.3: National Socialist NS-Frauen Warte, Heft 8, 1935-1936. Magazine reproduction. Universität Heidelberg, Heidelberg. https://digi.ub.uniheidelberg.de/diglit/frauenwarte1935_1936/0314/image 


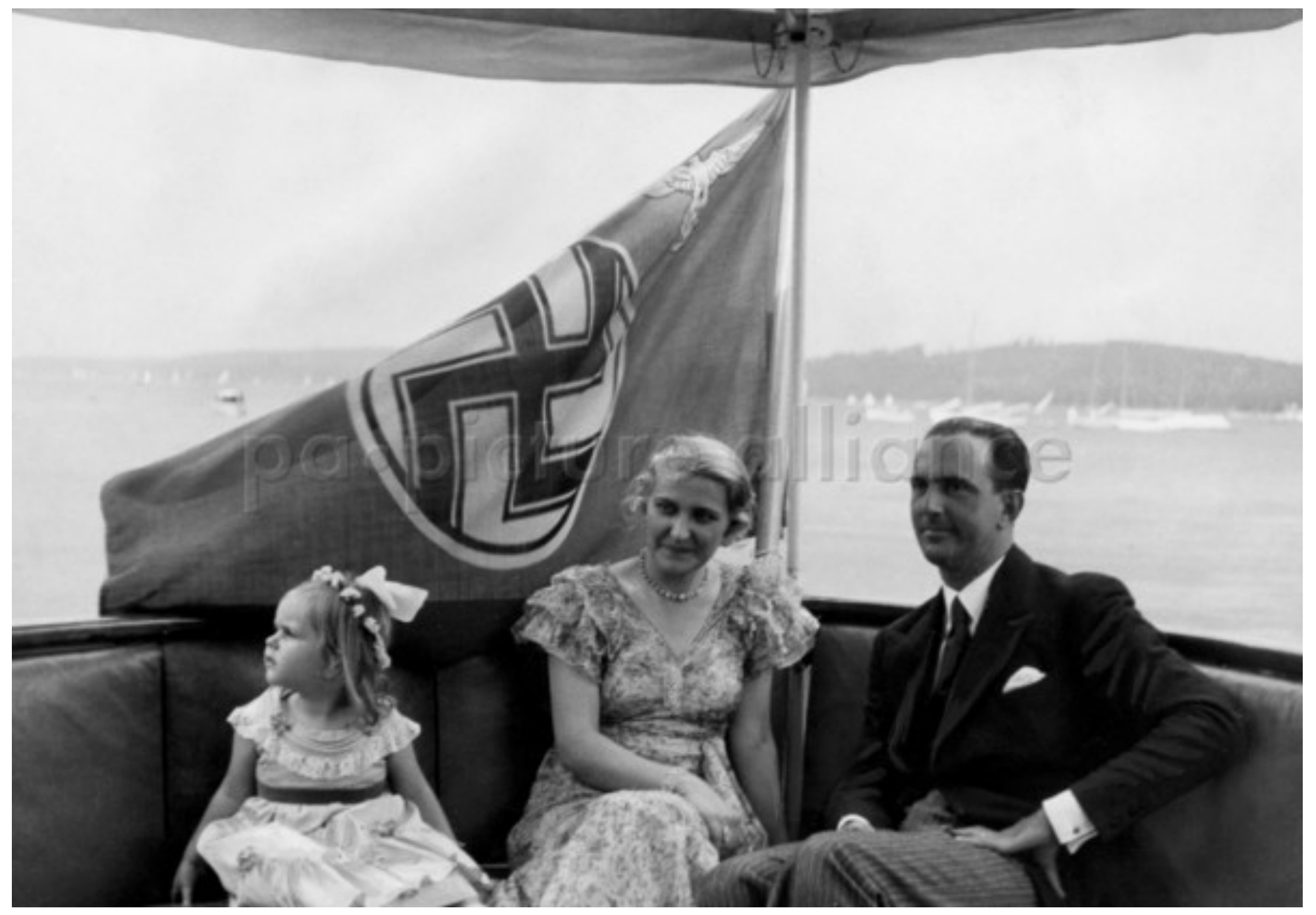

Figure 2.4: Heinrich Hoffmann, Magda Goebbels with her daughter Hilde and the Prince Umberto II of Savoyen during a boat trip on the Wannsee in Berlin, May 1936. Photograph. Berliner Morgenpost, August 5th, 1936. Ullstein Bild via Getty Images, Berlin. https://www.gettyimages.fr/detail/photo-d'actualit\%C3\%A9/goebbels-magda-wife-of-j-goebbelsgermany11-11-1945-photo-dactualit\%C3\%A9/543895541 


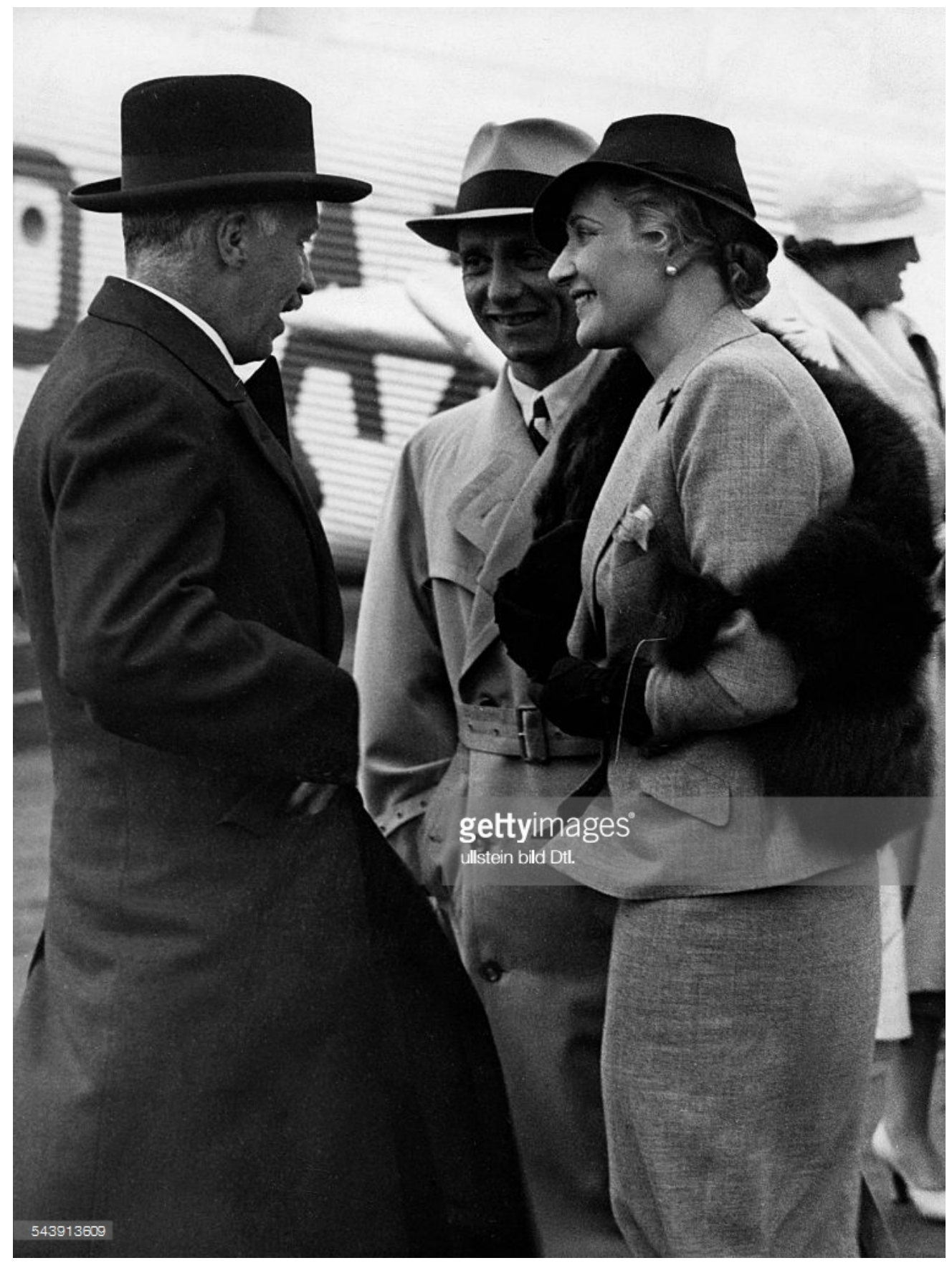

Figure 2.5: Heinrich Hoffmann, Magda and Joseph Goebbels just before getting on a plane to Greece talking to the Greek ambassador Alexander Rizo-Rangabe, 1936. Photograph. Das 12 Uhr Blatt on October 30, 1936. Ullstein Bild via Getty Images, Berlin.

https://www.gettyimages.fr/detail/photo-d'actualit\%C3\%A9/goebbels-joseph-politician-nsdapgermany29-10-1897-photo-dactualit\%C3\%A9/543913609 


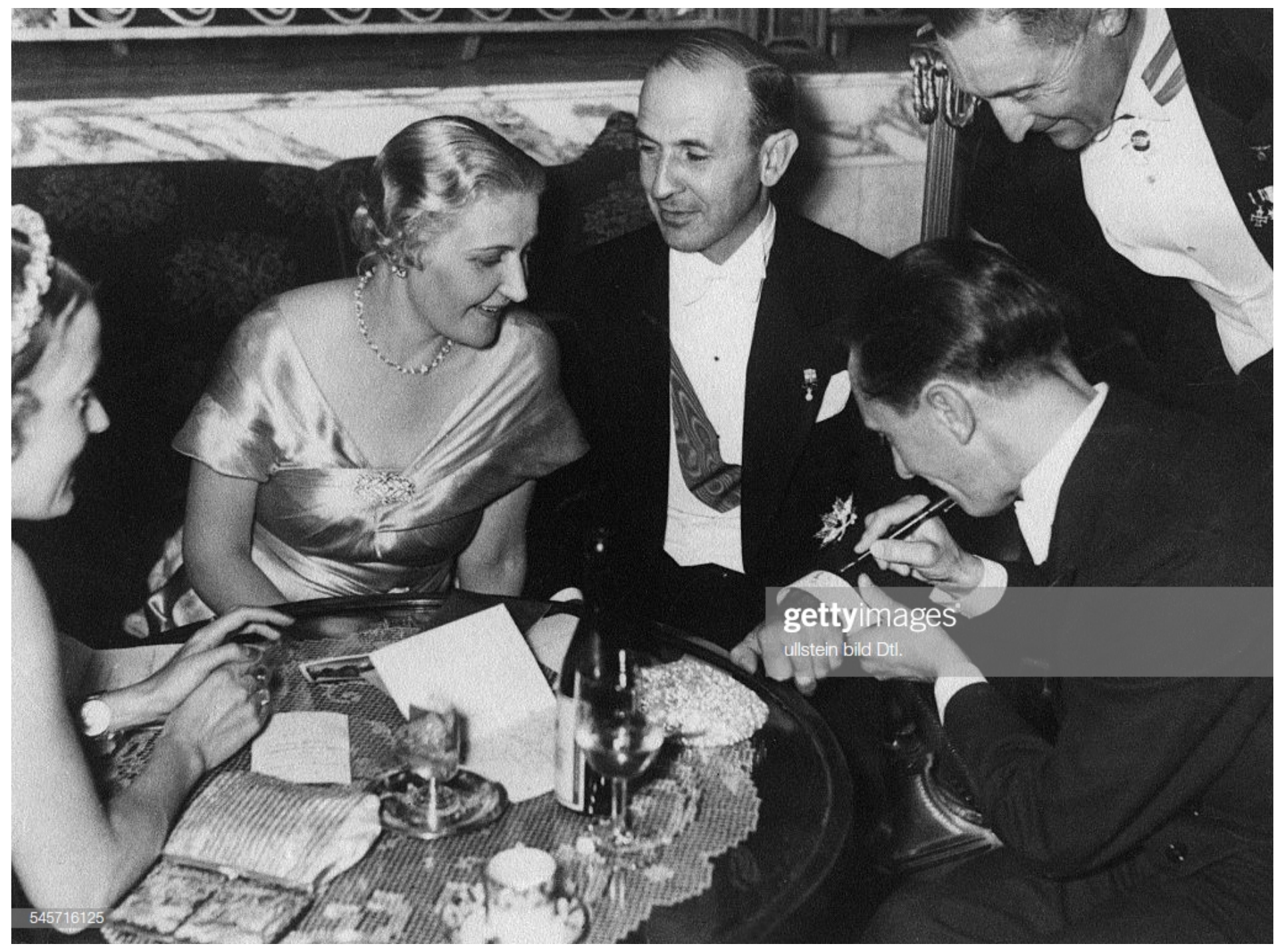

Figure 2.6: Magda Goebbels with Mrs. Altenberg, Propaganda Minister Dino Alfieri, Dr. Fred C. Willis, the head of the Italy Division in the Reich Ministry of Propaganda and Joseph Goebbels at the official reception for the International Association of the Union of Writers and Composers at the Hotel Kaiserhof in Berlin, 1938. Photograph. Ullstein Bild via Getty Images, Berlin. https:/www.gettyimages.fr/detail/photo-d'actualit $\% \mathrm{C} 3 \% \mathrm{~A} 9 /$ congress-of-theconfederation-internationale-des-photo-dactualit\%C3\%A9/545716125 


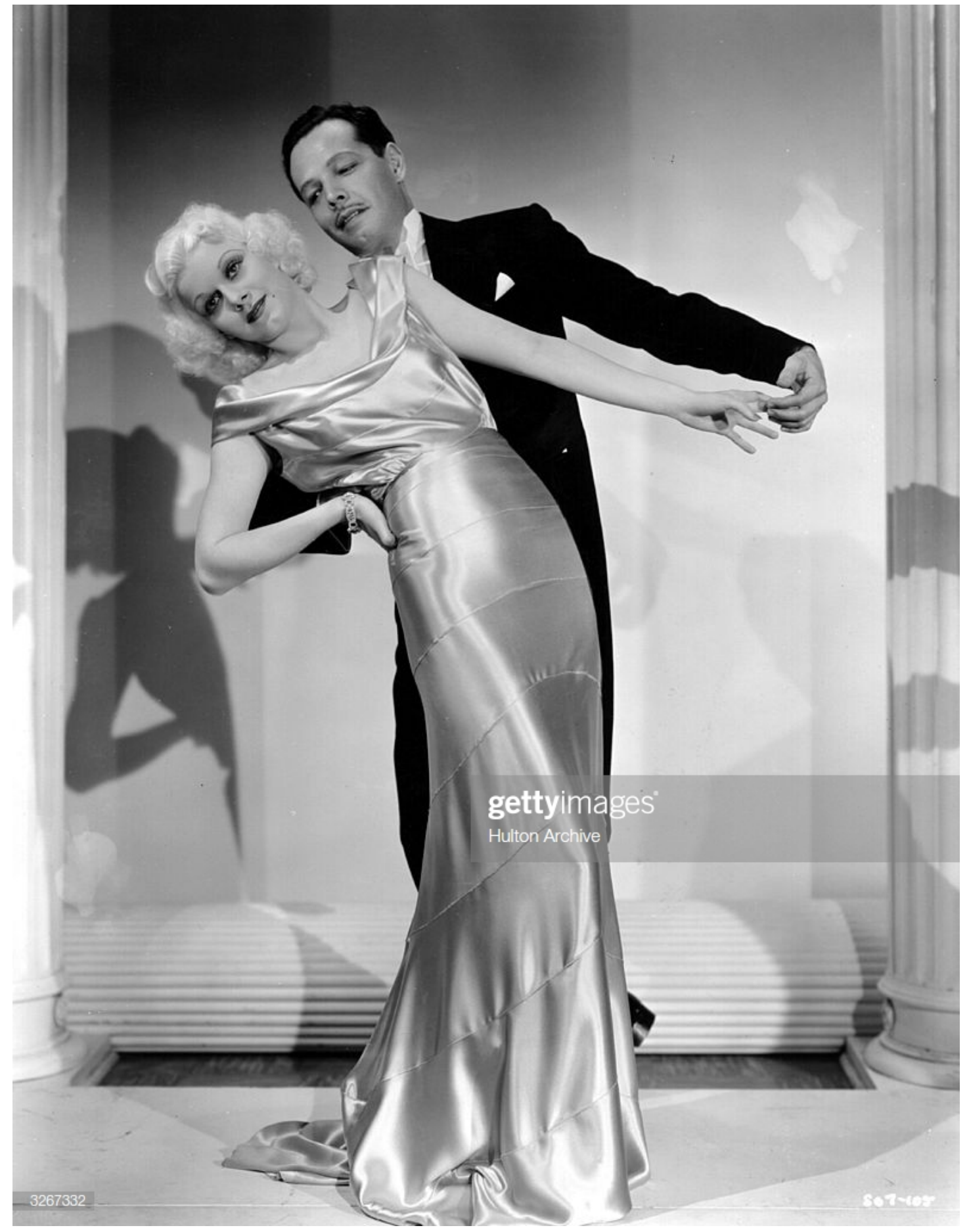

Figure 2.7: Jean Harlow dancing with Carl Randall in the Hollywood movie Reckless, 1935. Photograph. Getty Images. https://www.gettyimages.fr/detail/photo-d'actualit\%C3\%A9/newsensational-dance-team-is-introduced-in-the-photo-dactualit $\% \mathrm{C} 3 \% \mathrm{~A} 9 / 517457058$ 


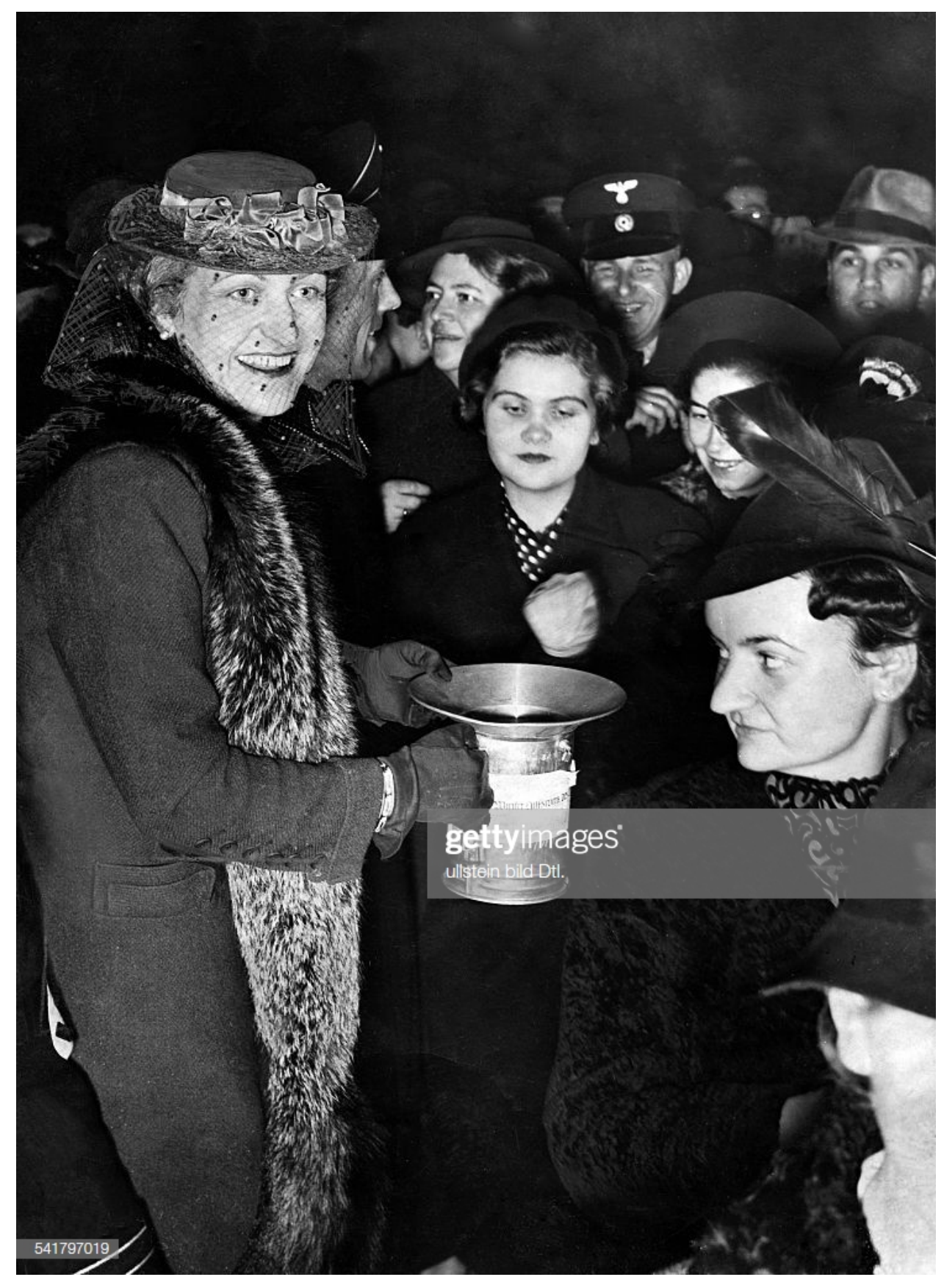

Figure 2.8: Heinz Fremcke, Magda Goebbels at the annual Day of National Solidarity for the Winter Relief in Berlin, 1938. Photograph. Berliner Morgenpost, December 4, 1938. Ullstein Bild via Getty Images, Berlin. https://www.gettyimages.fr/detail/photod'actualit\%C3\%A9/german-empire-free-state-prussia-brandenburg-provinz-photodactualit $\%$ C3\%A9/541797019 


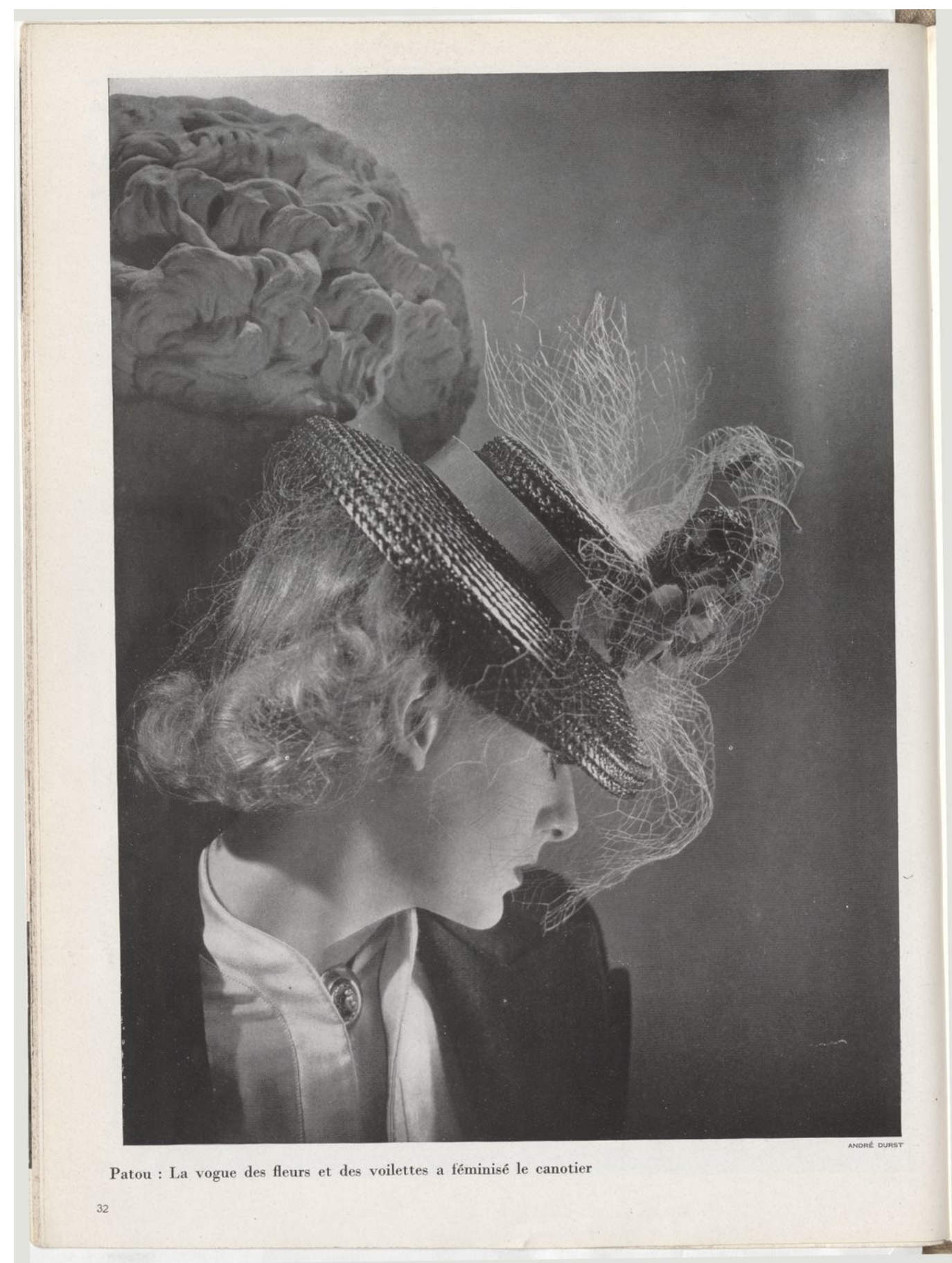

Source gallica.bnf.fr / Bibliothèque nationale de France

Figure 2.9: "Savoir Choisir," Vogue Paris, February 1939. Magazine Reproduction. Gallica, Bibliothèque Nationale de France, Paris. The model is wearing a Jean Patou hat. https://gallica.bnf.fr/ark:/12148/bpt6k6542633k/f34.item 

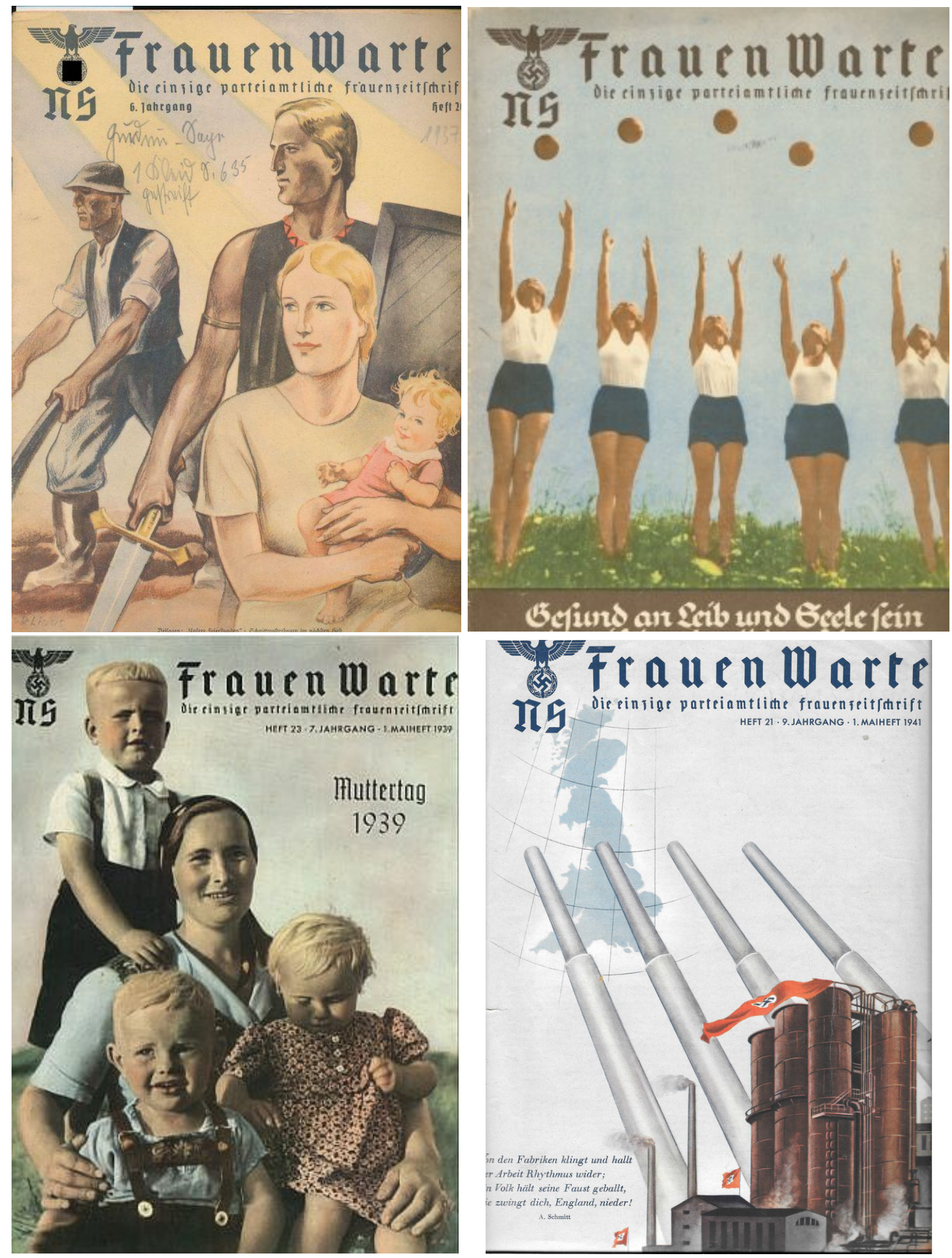

Figure 2.10 a-d: National Socialist NS-Frauen Warte, February 1937. Heft 19, 1938. Heft 23, Maiheft 1939. Heft 21, Maiheft 1941. Magazine reproduction. 


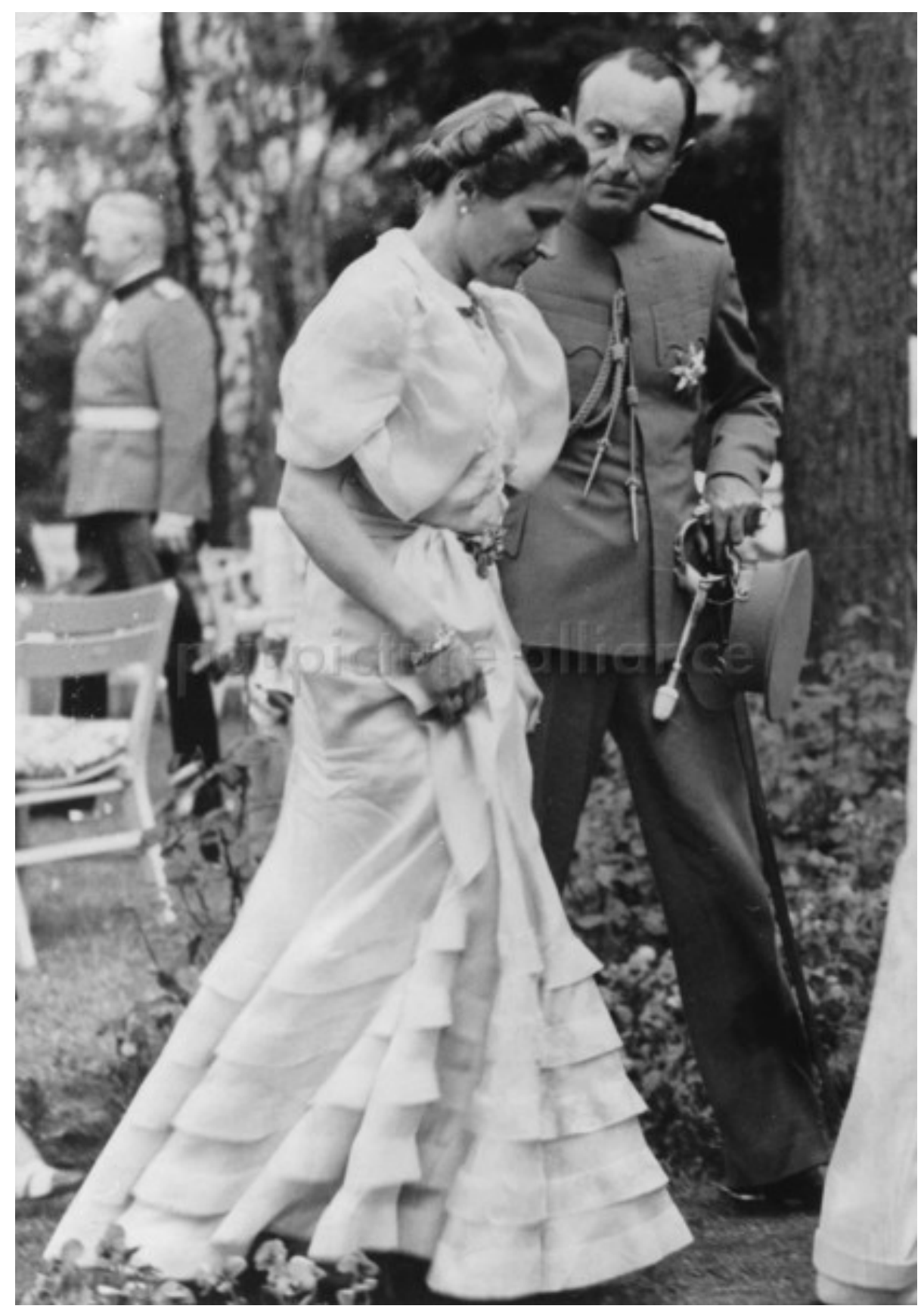

Figure 2.11: Heinrich Hoffmann, Magda Goebbels walking next to the Prince Paul of Yugoslavia at the Goebbels' villa on Schwanenwerder Island, June 1939. Photograph. Berliner Illustrierte Zeitung, June 3rd, 1939. Ullstein Bild via Getty Images, Berlin. https://www.gettyimages.fr/detail/photo-d'actualit\%C3\%A9/relations-germany-yugoslavia-paulof-yugoslavia-on-a-photo-dactualit $\% \mathrm{C} 3 \% \mathrm{~A} 9 / 545956539$ 


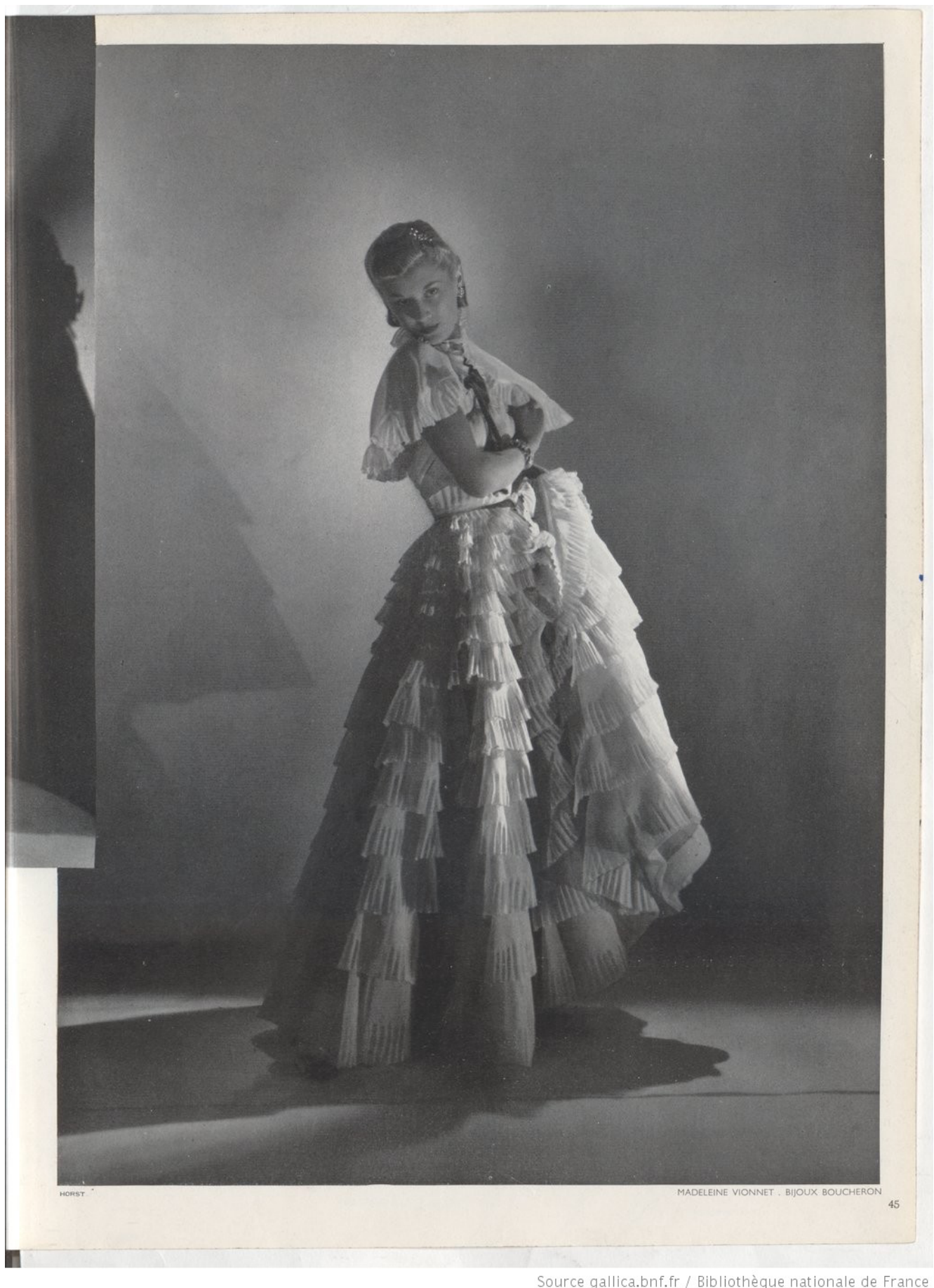

Figure 2.12: "Mousseline et Dentelle," Vogue Paris, June 1939. The model is wearing a Madeleine Vionnet dress. Magazine Reproduction. Gallica, Bibliothèque Nationale de France, Paris. https://gallica.bnf.fr/ark:/12148/bpt6k65426377/f47.item 


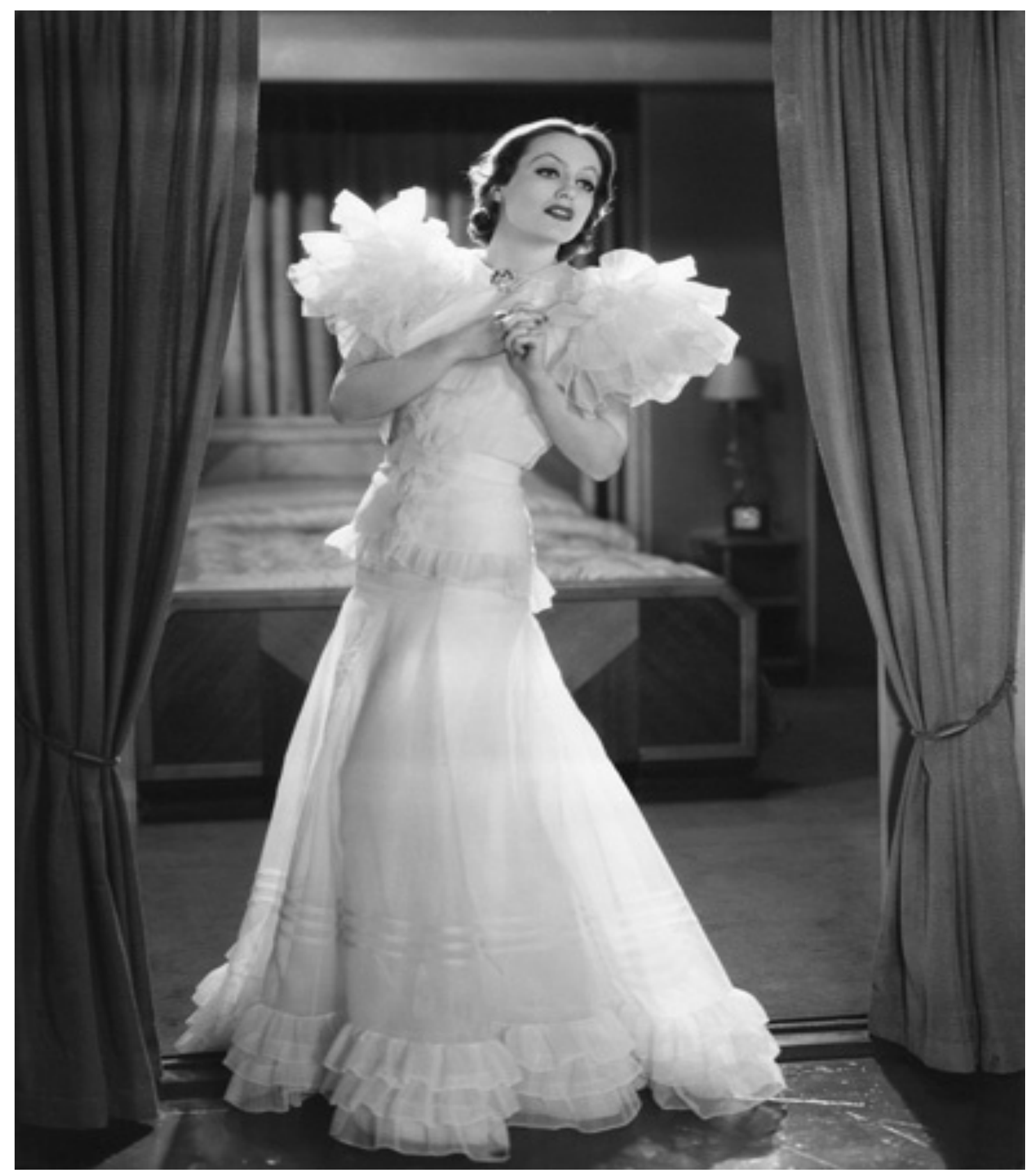

Figure 2.13: Actress Joan Crawford in the movie Letty Lyon, 1932. Motion Pictures Still. Metro-Goldwyn-Mayer. 


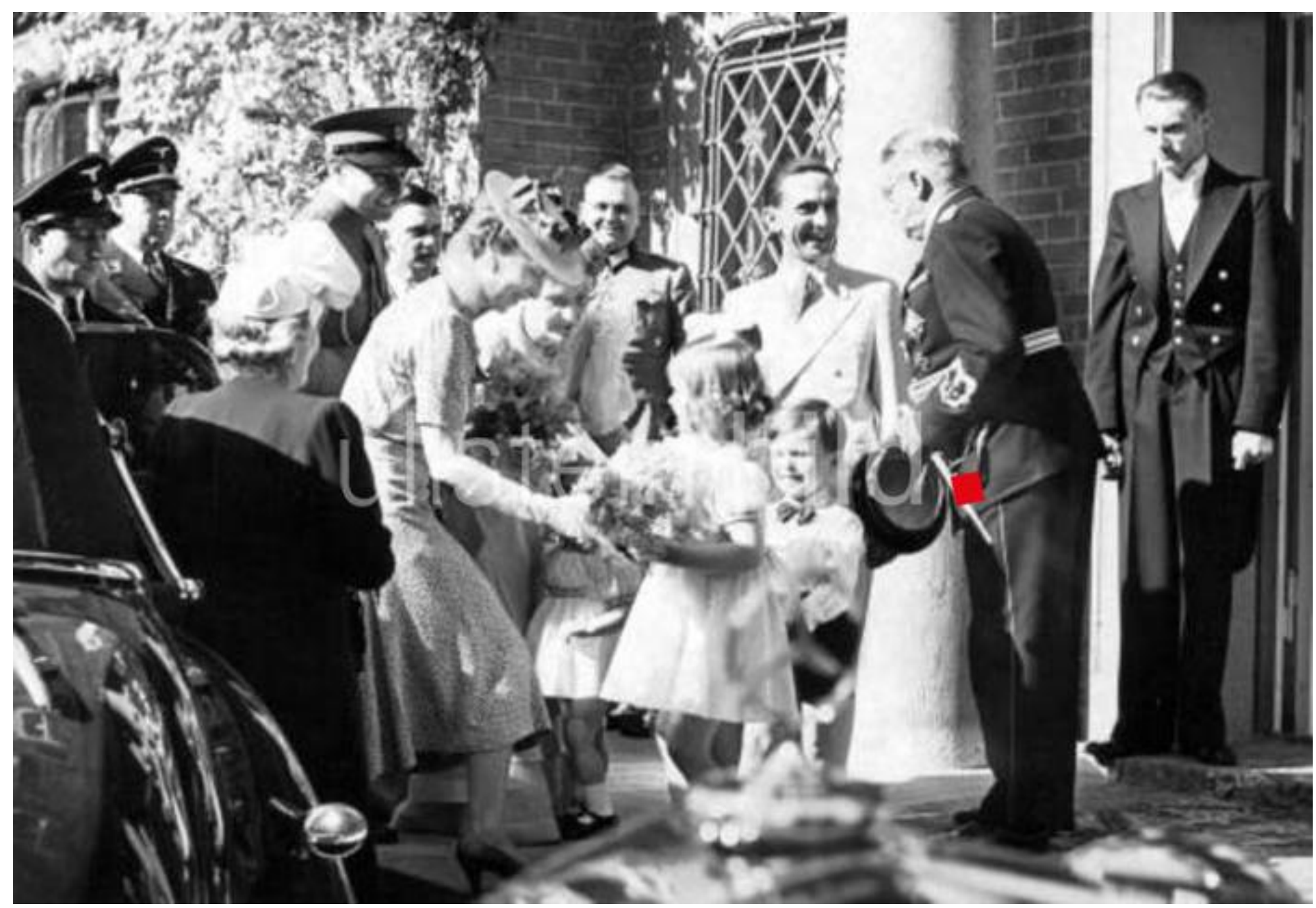

Figure 2.14: Joseph and Magda Goebbels (and their kids) welcome the prince and princess of Yugoslavia during an official visit to the Goebbels' villa on the Schwanenwerder Island, 1939. Photograph. 00273446, Ullstein Bild, Berlin. https://www.ullsteinbild.de/?82231788017539342720

The Princess of Yugoslavia can be seen at the front wearing a short sleeve polka-dot dress and a hat. 


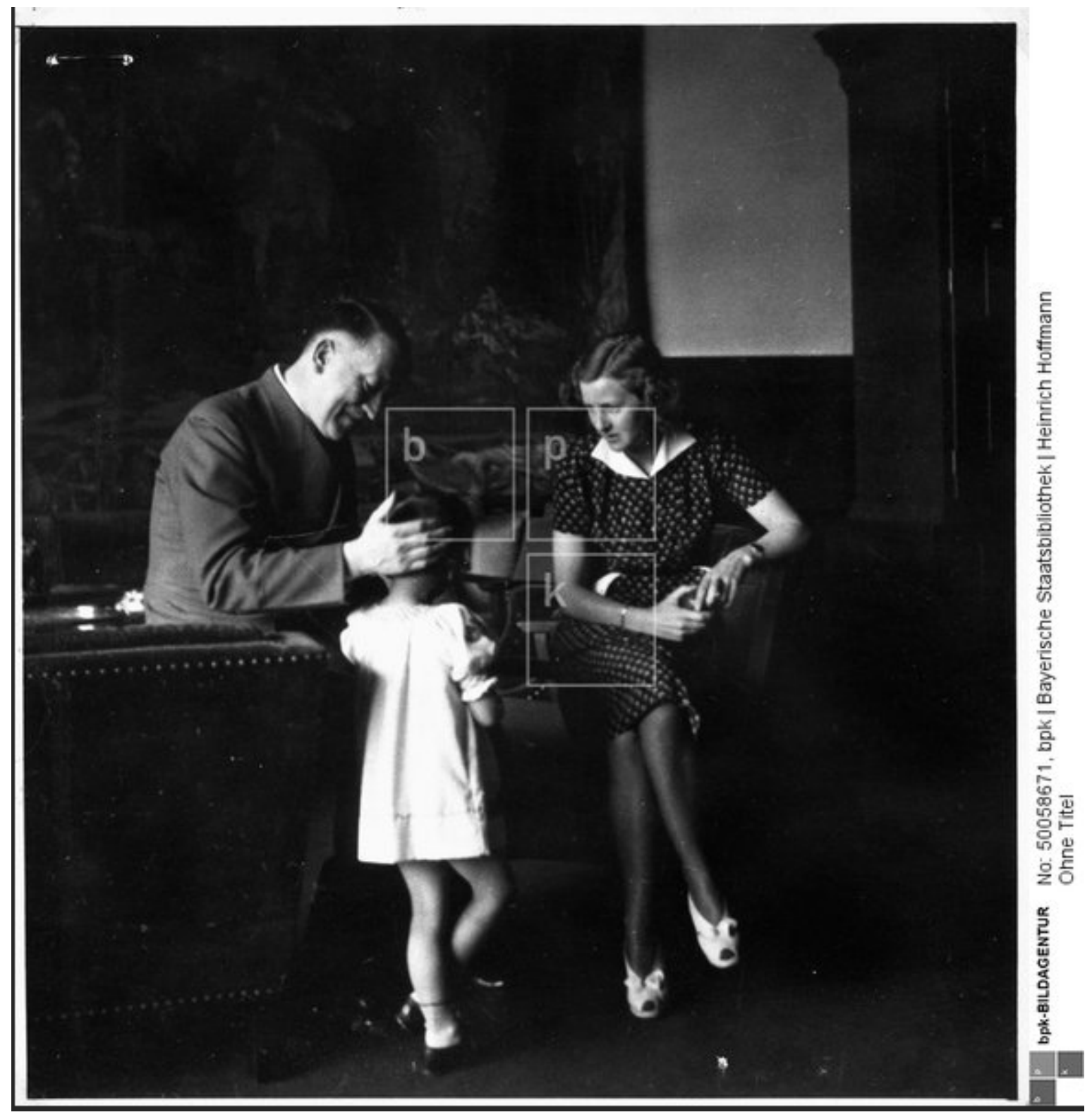

Figure 3.1: Heinrich Hoffmann, Eva Braun and Adolf Hitler with Uschi Schneider (the daughter of Braun's friend Herta Schneider) at the Berghof, 1937. Photograph. Bayerische Staatsbibliothek, Munich. 50058671.

https://www.bpk-bildagentur.de/shop 


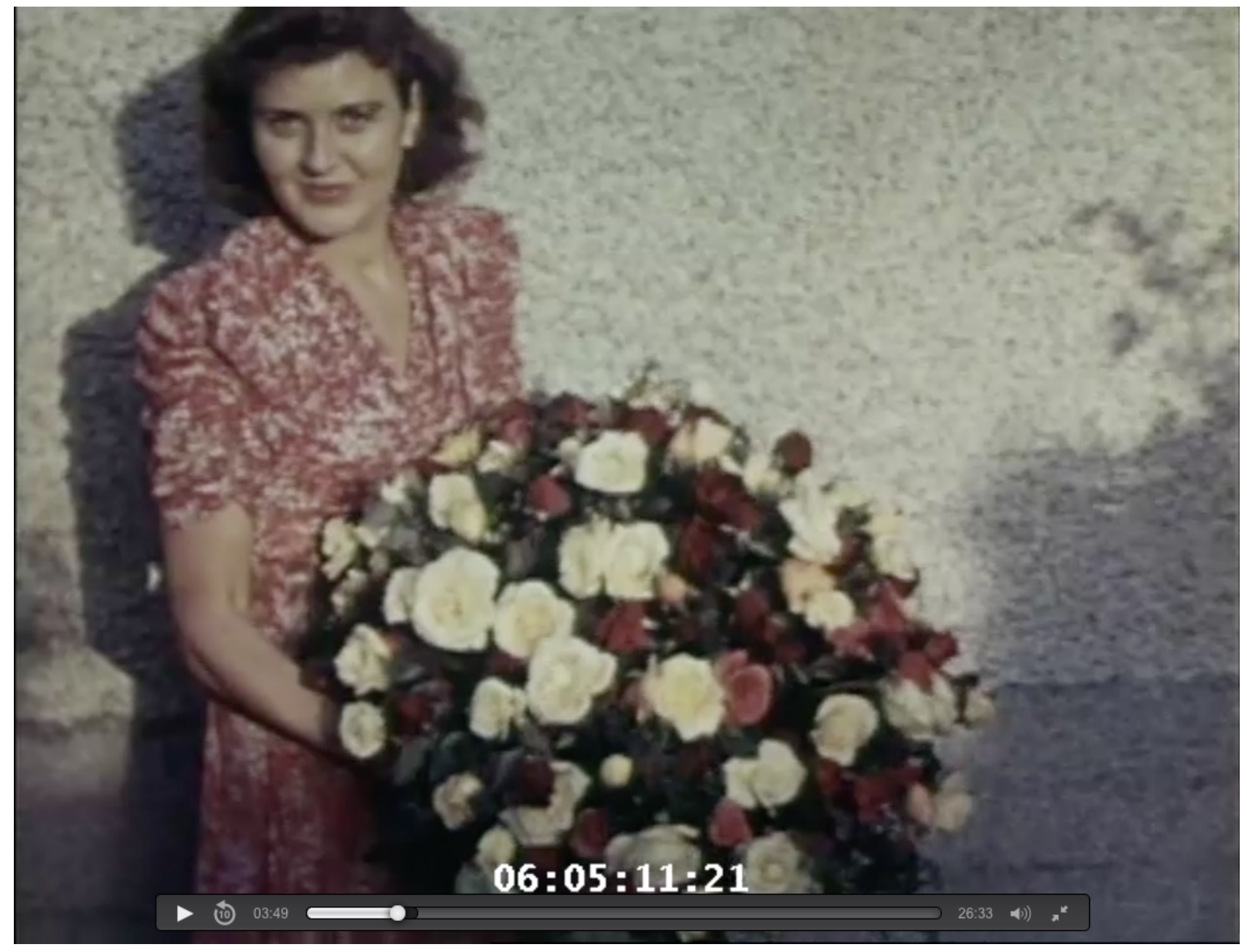

Figure 3.2: Reel 7 of the private motion pictures of Eva Braun. 1939-1940. Film. United States Holocaust Memorial Museum, Seized Enemy Records, 1994.119.1, RG-60.0944. https://collections.ushmm.org/search/catalog/irn1000806 


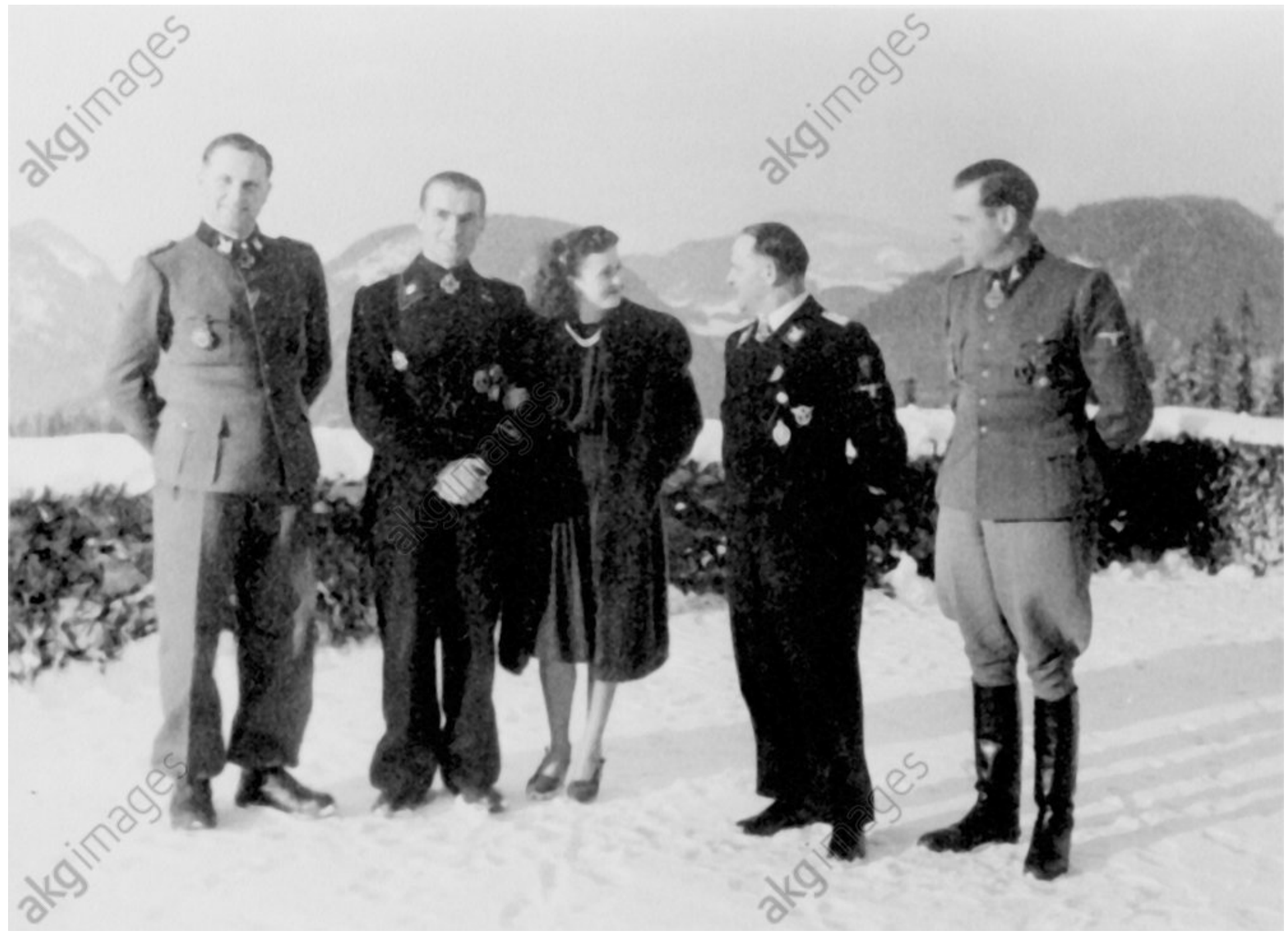

Figure 3.3: Eva Braun With Visitors on the Berghof Terrace, 1942, Photography, Eva Braun's Personal Photos Album, AKG Image. https://www.akgimages.fr/CS.aspx?VP3=SearchResult\&VBID=2UMESQ5L497QP9\&SMLS=1\&RW=1280\&R $\underline{\mathrm{H}=651 \# / \text { SearchResult\&VBID=2UMESQ5L497QP9\&SMLS=1\&RW=1280\&RH=651\&POPUP }}$ $\underline{\mathrm{PN}=9 \& \text { POPUPIID }=2 \mathrm{UMDHURH} 4 \mathrm{E} 73}$ 


\section{SOMPTUEUSES ÉCONOMIES}

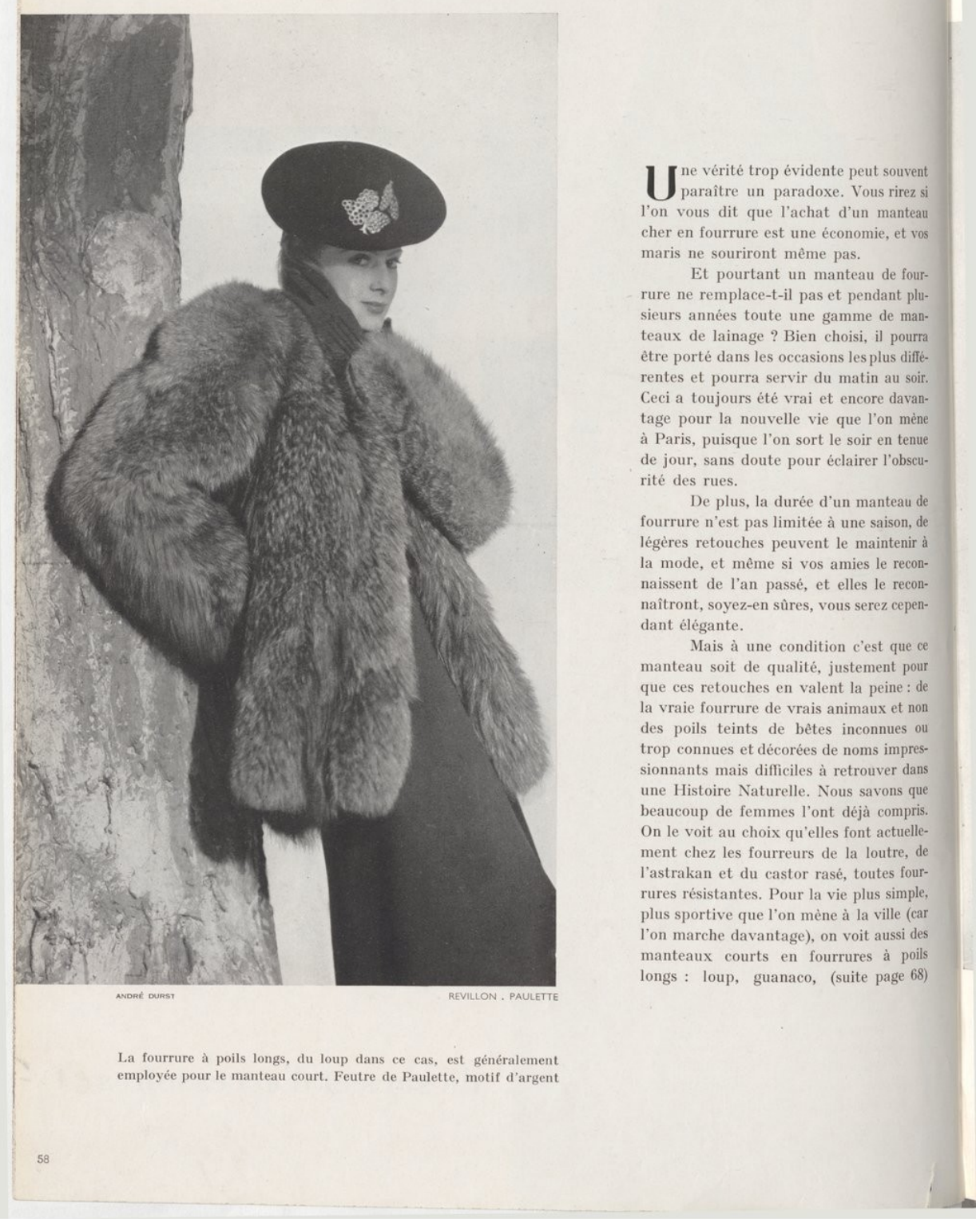

Source gallica.bnf.fr / Bibliothèque nationale de France

Figure 3.4: "Somptueuses Économies." Vogue Paris, December 1939. Magazine Reproduction. Gallica, Bibliothèque Nationale de France, Paris. https://gallica.bnf.fr/ark:/12148/bpt6k65426414/f60.item 


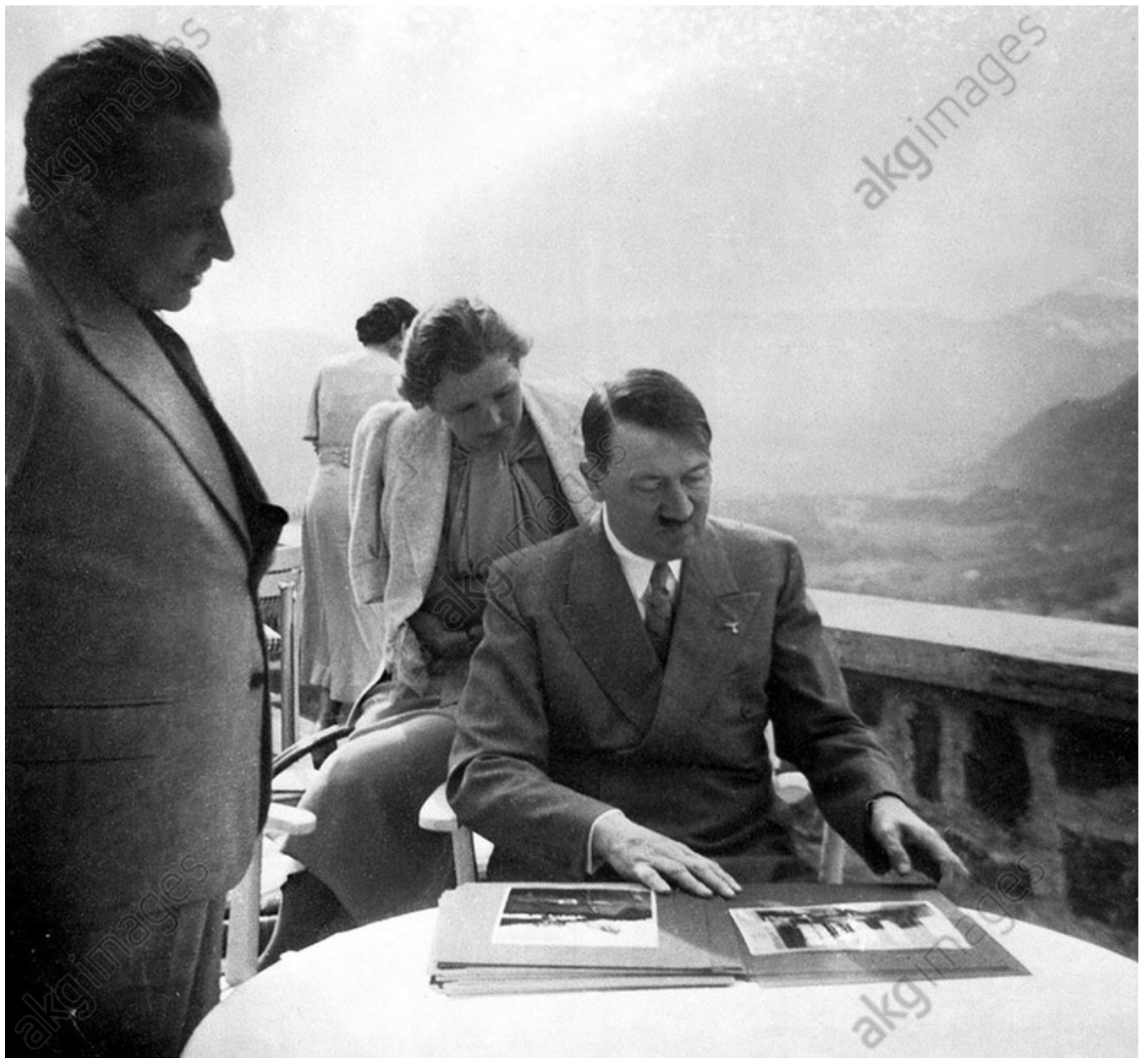

Figure 3.5: Eva Braun and Adolf Hitler looking at photographs brought by Heinrich Hoffmann (seen on the far left) on the terrace of the Berghof, 1942. Photograph. Heinrich Hoffmann's Archives, 50090175, Bayerische Staatsbibliothek, Munich.

https://www.bpk-bildagentur.de/shop 


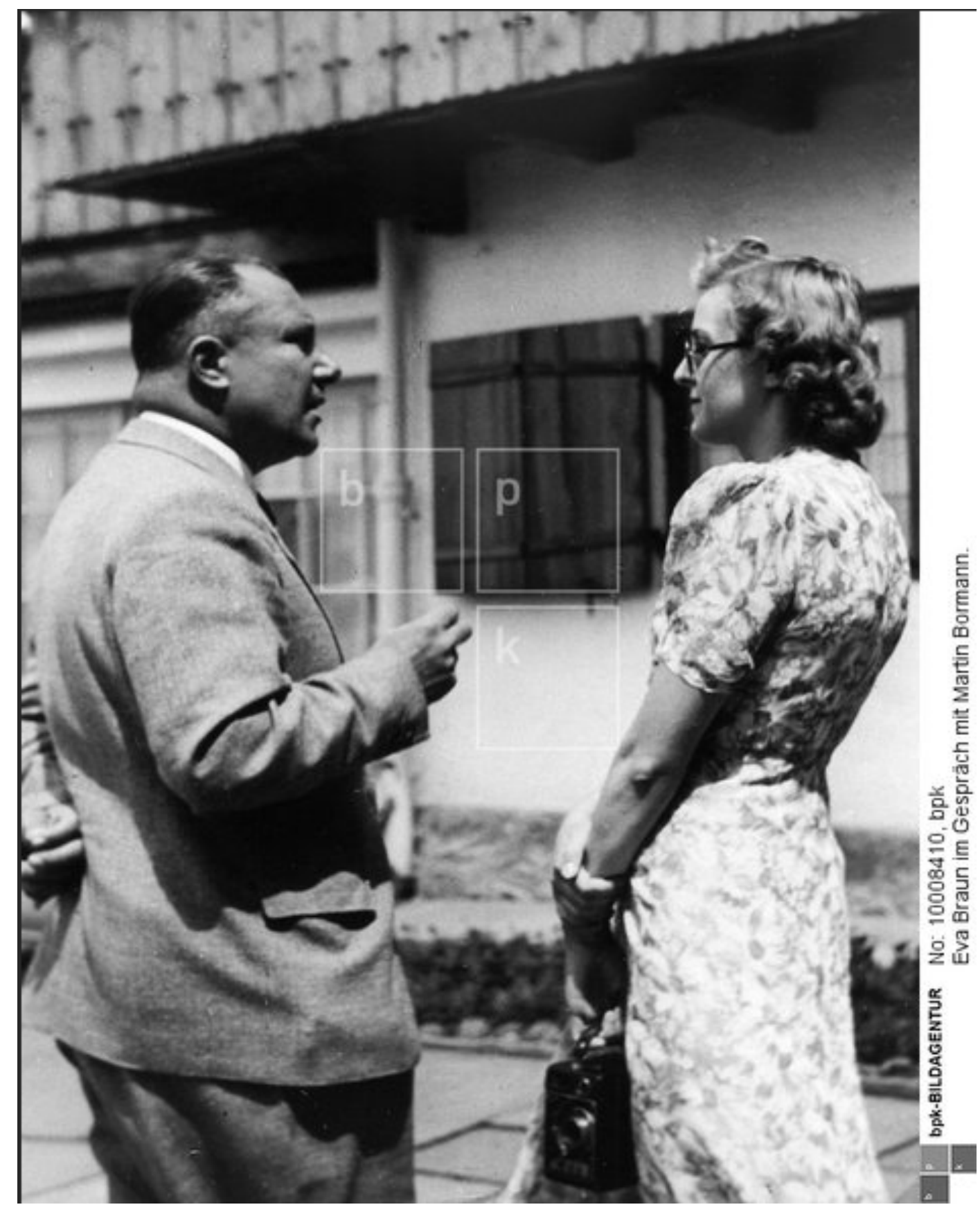

Figure 3.6: Eva Braun talking to Martin Bormann at the Berghof, 1944. Photograph. Eva Braun's Private Album. BPK-Bildagentur, Berlin. 10008410. https://www.bpkbildagentur.de/shop 


\section{BIBLIOGRAPHY}

Arendt, Hannah. Origins of Totalitarianism. Harcourt: Brace \& World, 1968.

Bailey, Margaret J. Those Glorious Glamour Years. New York: Citadel Press, 1982.

Barthes, Roland. Mythologies. Translated by Annette Lavers. London: Jonathan Cape, 1972.

Barthes, Roland. The Fashion System. Translated by Matthew Ward and Richard Howard. New York: Hill and Wang, 1983.

Baranowski, Shelley. Strength Through Joy: Consumerism and Mass Tourism in the Third Reich. Cambridge: Cambridge University Press, 2004.

Barnard, Malcolm. Fashion as Communication. London: Routledge, 1996.

Bartky, Sandra Lee. "Foucault, Femininity and the Modernization of Patriarchal Power." In Feminism \& Foucault: Reflections on Resistance, edited by Irene Diamond and Lee Quinby, 61-86. Boston: Northeastern University Press, 1988

Bleuel, Hans Peter. Strength Through Joy: Sex and Society in Nazi Germany. Translated by J. Maxwell Brownjohn. London: Secker \& Warburg, 1973.

Bock, Gisela. "Equality and Difference in National Socialist Racism." In Beyond Equality and Difference: Citizenship, Feminist Policies and Female Subjectivity, edited by Gisela Bock and Susan James, 82-101. London: Routledge, 1992.

Brashler, Karin Lynn. "Mothers of Germany: A Look at the Ideal Woman in Nazi Propaganda." Master's Thesis, Iowa State University, 2015. ProQuest (1592872)

Braun, Eva. Diary of Eva Braun. 1935. War Department: Military Intelligence Division 8. Writings Related to World War II, 1946 Series. 6921915. National Archives.

Chambers, Bernice G. Color and Design in Apparel. New York: Prentice-Hall Inc., 1945. 
Chandler, Daniel. Semiotics: The Basics. London: Routledge, 2002.

Cocks, Geoffrey. "Illness in the State of Health." In Life And Times in Nazi Germany, edited by Lisa Pine, 75-100. London: Bloomsbury, 2016.

Craik, Jennifer. The Face of Fashion: Cultural Studies in Fashion. London: Routledge, 1994.

Crane, Diana. Fashion and its Social Agendas: Class, Gender and Identity in Clothing. Chicago: The University of Chicago Press, 2000.

D'Almeida, Fabrice. High Society in the Third Reich. Translated by Steven Rendall. Cambridge: Polity Press, 2008.

D’Almeida, Fabrice. "Luxury and Distinction Under National Socialism.” In Pleasure and Power in Nazi Germany, edited by Pamela E. Swett, Corey Ross and Fabrice d'Almeida, 67-83. Basingstoke: Palgrave Macmillan, 2011.

Deutsch, Karl W. "Cracks in The Monolith: Possibilities and Patterns of Disintegration in Totalitarian Systems.” In Totalitarianism, edited by Carl J. Friedrick, 308-341. New York: The Universal Library, 1954.

De Witt, Thomas E.“The Struggle Against Winter and Cold: Winter Relief in Nazi Germany, 1933-1939." Canadian Journal of History 12, no.3 (February 1978): 361-381.

Duncan, Margaret Carlisle. “The Politics of Women's Body Images and Practices: Foucault, the Panopticon, and Shape Magazine.” Journal of Sport \& Social Issues 18, no. 1 (1994): 4865.

Entwistle, Joanne

Elizabeth Wilson, eds. Body Dressing. Oxford: Berg, 2001.

Entwistle, Joanne. “'Power Dressing' and the Construction of the Career Woman.” In Fashion Theory: A Reader, edited by Malcolm Barnard, 208-219. Milton Park: Routledge, 2007. 
Entwistle, Joanne. The Fashioned Body: Fashion, Dress and Modern Social Theory. Cambridge, Polity Press, 2000.

Epstein, Catherine. Nazi Germany: Confronting the Myths. Chichester: John Wiley \& Sons, 2015 ,

Eva Braun’s Assets. 5 March 1948. Inventory Shipment No.76. National Archives.

Fiell, Charlotte, and Emmanuelle Dirix, eds. 1930s Fashion: The Definitive Sourcebook. London: Goodman Fiell, 2012.

Foucault, Michel. Discipline and Punish: The Birth of the Prison. Translated by Alan Sheridan. New York: Random House, 1995.

Foucault, Michel. “Panopticism' from Discipline \& Punish: The Birth of the Prison.” Race/Ethnicity: Multidisciplinary Global Contexts 2, no.1 (Autumn 2008): 1-12.

Foucault, Michel. Power/knowledge: Selected Interviews and Other Writings, 1972-1977. Edited by Colin Gordon. New York: Pantheon Books, 1980.

Foucault, Michel. "Society Must Be Defended” Lectures At the Collège de France, 1975-76. Edited by Mauro Bertani, Alessandro Fontana and François Ewald. Translated by David Macey. New York: Picador, 1997.

Foucault, Michel. “The Subject and Power.” Critical Inquiry 8, no. 4 (Summer 1982): 777-795.

Frenkel-Brunswick, Else. “The Role of Psychology in The Study of Totalitarianism.” In Totalitarianism, edited by Carl J. Friedrick, 171-202. New York: The Universal Library, 1954.

Fricke, Heike. "Ingrid Larssen: A Female Saxophonist in the Nazi Era." Journal of the American Musical Instrument Society 40 (2014): 190-274.

Friedrick, Carl J. ed. Totalitarianism. New York: The Universal Library, 1954. 
Führer, Karl Christian. "Pleasure, Practicality and Propaganda: Popular Magazines in Nazi Germany, 1933- 1939.” In Pleasure and Power in Nazi Germany, edited by Pamela E. Swett, Corey Ross and Fabrice d'Almeida, 132-153. Basingstoke: Palgrave Macmillan, 2011.

Görtemaker, Heike B. Eva Braun: Life With Hitler. Translated by Damion Searls. New York: Alfred A. Knopf, 2011.

Gudgel, Mark. "Distinctive Dress of the Nazi Party." In Berg Encyclopedia of World Dress and Fashion: West Europe, edited by Lise Skov. Oxford: Berg, 2010. Accessed February 10, 2019. http://dx.doi.org.ezproxy.lib.ryerson.ca/10.2752/BEWDF/EDch8811.

Guenther, Irene. "Nazi ‘Chic’? German Politics and Women's Fashions, 1915-1945.” Fashion Theory 1, no.1 (2015): 29-58.Guenther, Irene. Nazi Chic? Fashioning Women in the Third Reich. Oxford: Berg, 2004.

Guenther, Irene. "Fashioning Women in The Third Reich.” In Life And Times in Nazi Germany, edited by Lisa Pine, 101-130. London: Bloomsbury, 2016.

Gun, Nerin E. Eva Braun: Hitler's Mistress. New York: Meredith Press, 1968.

Gurung, Regan A. R., Michaella Brickner, Mary Leet, and Elizabeth Punke. "Dressing 'in Code': Clothing Rules, Propriety, and Perceptions.” The Journal of Social Psychology 158, no. 5 (2018): 553-557.

Hamann, Brigitte. Hitler's Vienna: A Portrait of the Tyrant as a Young Man. Oxford: Oxford University Press, 1999.

Hofmann, Annette R. “Christl Cranz, Germany's Ski Icon of the 1930s: The Nazis' Image of the Ideal German Woman?” Sport in Society 20, no.8 (2017): 1013-1029. 
Homberger, Torsten, and Linda Arthur Bradley. 'Nazi Dress: Hitler's Storm Troopers and Appearance Management, 1921-1933." Critical Studies in Men's Fashion 2, no.2-3 (2015): 183-197.

Horn, Marilyn J., and Lois M. Gurel. The Second Skin: An Interdisciplinary Study of Clothing. 3rd ed. Boston: Houghton Mifflin Company, 1981.

Inkeles, Alex. "The Totalitarian Mystique: Some Impressions of the Dynamics of Totalitarian Society.” In Totalitarianism, edited by Carl J. Friedrick, 87-108. New York: The Universal Library, 1954.

Jahoda, Marie, and Stuart W. Cook. "Ideological Compliance as a Social-Psychological Process.” In Totalitarianism, edited by Carl J. Friedrick, 203-230. New York: The Universal Library, 1954.

Jenss, Heike, ed. Fashion Studies: Research Methods, Sites, and Practices. London: Bloomsbury Academic, 2016.

Jobling, Paul. "Roland Barthes: Semiology and the Rhetorical Codes of Fashion.” In Thinking Through Fashion: A Guide to Key Theorists, edited by Agnès Rocamora and Anneke Smelik, 132-148. London: I.B. Tauris, 2016.

Junge, Traudl. "My Time with Adolf Hitler." Written in 1947. In Until the Final Hour: Hitler's Last Secretary, edited by Melissa Müller, translated by Anthea Bell, 27-215. London: Weidenfeld \& Nicolson, 2003.

Kaiser, Susan. The Social Psychology of Clothing: Symbolic Appearances in Context. 2nd ed. New York: McMillan, 1990.

Keenan, William J.F. Dressed to Impress: Looking the Part. London: Berg, 2001. 
Kallis, Aristotle. "Nazi Propaganda and 'Coordination': The Haphazard Path to Totalitarianism." European Review of History 13, no.1 (March 2006): 115-139.

Klabunde, Anja. Magda Goebbels. Translated by Shaun Whiteside. London: Little, Brown, 2001.

Knopp, Guido. Hitler's Women. Translated by Angus McGeoch. New York: Routledge, 2003.

Koonz, Claudia. The Nazi Conscience. Cambridge: The Belknap Press of Harvard University Press, 2003.

Koonz, Claudia. Mothers in the Fatherland: Women, the Family and Nazi Politics. New York: St. Martin's Press, 1987.

Kremer, Roberta S. ed. Broken Threads: The Destruction of the Jewish Fashion Industry in Germany and Austria. Oxford: Berg, 2007.

Lambert, Angela. The Lost Life of Eva Braun. New York: St Martin’s Press, 1984.

Lauer, Jeanette C., and Robert H. Lauer. Fashion Power: The Meaning of Fashion in American Society. Englewood Cliffs: Prentice Halls, 1981.

Lauterbach, Albert. “Totalitarian Appeal and Economic Reform.” In Totalitarianism, edited by Carl J. Friedrick, 281-296. New York: The Universal Library, 1954.

Leck, Ralph M. "Theoretical Issues: Conservative Empowerment and the Gender of Nazism: Paradigms of Power and Complicity in German Women's History." Journal of Women's History 12, no. 2 (2000): 147-169.

Lurie, Alison. The Language of Clothes. New York: Random House, 1981.

MacDonell Smith, Nancy. The Classic Ten: The True Story of the Little Black Dress and Nine Other Fashion Favorites. London: Penguin Books, 2003.

Makela, Maria. "The Rise and the Fall of the Flapper Dress: Nationalism and Anti-Semitism." Journal of Popular Culture 34, no.3 (2000): 183-208 
Marcketti, Sara B., and Emily Thomsen Angstman. "The Trend for Mannish Suits in the 1930s." Dress 39, no. 2 (2013): 135-152.

Marschik, Matthias. "A Fascinating Spectacle of Inconsistencies: Eroticism in the Nazi era." European Journal of Cultural Studies 6, no.1 (2003): 95-116.

McCloskey, Barbara. "Marking Time: Women and Nazi Propaganda Art during World War II." Contemporaneity 2, no.1 (2012): 1-17.

McDonald, Kenneth D. "Fascist Fashion: Dress, the State, and the Clothing Industry in the Third Reich.” PhD diss., University of California, 1998. (UMI 9913660).

McDonough, Frank. Hitler and the Rise of the Nazi Party. New York: Routledge, 2012.

Meissner, Hans Otto. Magda Goebbels: The First Lady of the Third Reich. Translated by Gwendolen Mary Keeble. New York: The Dial Press, 1980.

Merleau-Ponty, Maurice. Phenomenology of Perception. Translated by Colin Smiths. London: Routledge, 1962.

Merleau-Ponty, Maurice. The World of Perception. Translated by Oliver Davis. London: Taylor \& Francis Group, 2008.

Mills, Sara. Michel Foucault. London: Routledge, 2003.

Moore, Monica M., and Gwyneth I. Williams. "No Jacket Required: Academic Women and the Problem of the Blazer." Fashion, Style \& Popular Culture 1, no. 3 (2014): 359-376.

Mulvagh, Jane. Vogue History of the $20^{\text {th }}$ Century Fashion. London: Viking, 1988.

Negrin, Llewellyn. "Maurice Merleau-Ponty: The Corporeal Experience of Fashion.” In Thinking Through Fashion: A Guide to Key Theorists, edited by Agnès Rocamora and Anneke Smelik, 115-131. London: I.B. Tauris, 2016. 
Nelson, Cortney D. “Our Weapon is the Wooden Spoon: Motherhood, Racism, and War: The Diverse Roles of Women in Nazi Germany.” Master's Thesis, East Tennessee State University, 2014. ProQuest (1527180).

Nicholas, Lynn H. The Rape of Europa: The Fate of Europe's Treasures in the Third Reich and the Second World War. New York: Knopf, 1994.

Parkins, Wendy, ed. Fashioning the Body Politic: Dress, Gender, Citizenship. Oxford: Berg Publishers, 2002. Accessed March 10, 2019. http://dx.doi.org.ezproxy.lib.ryerson.ca/10.2752/9781847888723.

Pastoureau, Michel. Blue: The History of a Color. Princeton: Princeton, University Press. 2001. Pastoureau, Michel, and Jody Gladding. Red: The History of a Color. Princeton: Princeton University Press, 2017.

Pauley, Bruce F. Hitler, Stalin and Mussolini: Totalitarianism in the Twentieth Century. 4th ed. Chichester: John Wiley \& Sons, Inc, 2015.

Paxton, Robert O. The Anatomy of Fascism. New York: Vintage Books, 2004.

Petropoulos, Jonathan. Royals and The Reich: The Princes Von Hessen in Nazi Germany. New York: Oxford University Press, 2006.

Reuth, Ralf Georg. Goebbels. Translated by Krishna Winston. New York: Harcourt Brace \& Company, 1993.

Reagin, Nancy. "Tischkultur: Food Choices, Cooking and Diet in Nazi Germany." In Life And Times in Nazi Germany, edited by Lisa Pine, 21-47. London: Bloomsbury, 2016. Roach, Mary Ellen, and Joanne Bubolz Eicher. “The Language of Personal Adornment.” In Fashion Theory: A Reader, edited by Malcolm Barnard, 109-125. Milton Park: Routledge, 2007. 
Rossy, Katherine M. "Politicizing Pronatalism: Exploring the Nazi Ideology of Women Through the Lens of Visual Propaganda." The Graduate History Review 3, no.1 (2011): 49-77.

Rubinstein, Ruth P. Dress Codes: Meanings and Messages in American Culture. 2nd ed. Boulder: Westview Press, 2001.

Rupp, Leila J. "Mother of the 'Volk': The Image of Women in Nazi Ideology." Signs 3, no. 2 (1977): 362-379.

Rust, Victoria Vygodskaia. “Fashioning Women Under Totalitarian Regimes: 'New Women' of Nazi Germany and Soviet Russia.” PhD diss., Washington University, 2012.

Saussure, Ferdinand de. Course in General Linguistics. Edited by Perry Meisel and Haun Saussy. Translated by Wade Baskin. 3rd ed. New York: Columbia University Press, 2011.

Sheridan, Alan. Michel Foucault: The Will to Truth. London: Routledge, 1990.

Sigmund, Anna Maria. Women of the Third Reich. Richmond Hill: NDE Publishing, 2000.

Simmel, Georg. “Fashion.” American Journal of Sociology 62, no. 6 (1957): 541-558.

Stephenson, Jill. Women in Nazi Society. New York: Harper \& Row Publishers, 1975.

Stewart, Jude. Patternalia: An Unconventional History of Polka Dots, Stripes, Plaid, Camouflage \& Other Graphic Patterns. New York: Bloomsbury, 2015.

Stoltzfus, Nathan. Hitler's Compromises: Coercion and Consensus in Nazi Germany. New Haven: Yale University Press, 2016.

The Washington Post. "Pictures of Mysterious Baby Found in Eva Braun Treasures." November $16,1945$. 
Tynan, Jane. "Michel Foucault: Fashioning the Body Politic." In Thinking Through Fashion: A Guide to Key Theorists, edited by Agnès Rocamora and Anneke Smelik, 184-199. London: I.B. Tauris, 2016.

Urwand, Ben. Collaboration: Hollywood's Pact with Hitler. Cambridge: The Belknap Press of Harvard University Press, 2013.

Varley, Helen. ed., Colour. London: Marshall Editions Limited, 1980.

Wahl, Kimberly. "Purity and Parity: The White Dress of the Suffrage Movement in Early Twentieth-Century Britain.” In Colors in Fashion, edited by Jonathan Faiers and Mary Westerman Bulgarella, 21-33. London: Bloomsbury, 2017.

Wiesen, S. Jonathan. Creating The Nazi Marketplace: Commerce and Consumption in the Third Reich. New York: Cambridge University Press, 2011.

Wiesen, S. Jonathan. "Driving, Shopping and Smoking: The Society for Consumer Research and the Politics of Pleasure in Nazi Germany." In Pleasure and Power in Nazi Germany, edited by Pamela E. Swett, Corey Ross and Fabrice d'Almeida, 19-38. Basingstoke: Palgrave Macmillan, 2011.

Wilson, Elizabeth. Adorned in Dreams: Fashion and Modernity. London: I.B. Tauris, 2003.

Wimmer, Leila. “Modernity, Femininity and Hollywood Fashions: Women's Cinephilia in 1930s French Fan Magazines." Film, Fashion \& Consumption 3, no.1 (March 2014): 61-76.

Work, Robert E. "Last Days in Hitler's Air Raid Shelter.” The Public Opinion Quarterly 10, no.4 (Winter 1946-1947): 565-581.

"Die Deutsche Frau in Neuen Reich: Gespräch mit Magda Goebbels," Alpenzeitung, July 9, 1933. 
“Wettkämpfe Deutscher Mode: Frau Goebbels Über die Deutschen Frauen”, Vossische Zeitung, July 6, 1933. 